\title{
Molecular imaging findings on acute and \\ long-term effects of COVID-19 on the brain:
}

\section{A systematic review}

\author{
Philipp T. Meyer ${ }^{1}$, Sabine Hellwig ${ }^{2}$, Ganna Blazhenets ${ }^{1}$ and Jonas A. Hosp ${ }^{3}$ \\ ${ }^{1}$ Department of Nuclear Medicine, ${ }^{2}$ Department of Psychiatry and Psychotherapy \\ and ${ }^{3}$ Department of Neurology and Clinical Neuroscience \\ Medical Center - University of Freiburg, \\ Faculty of Medicine, University of Freiburg, Freiburg, Germany
}

\section{Corresponding author:}

Philipp T. Meyer, MD, PhD

Department of Nuclear Medicine

Medical Center - University of Freiburg

Hugstetter Strasse 55

79106 Freiburg, Germany

Phone: +4976127039160

Fax: $\quad+4976127039300$

Email: philipp.meyer@uniklinik-freiburg.de

Running head: Effects of COVID-19 on the brain

Conflicts of Interest: No potential conflicts of interest relevant to this article exist.

Immediate Open Access: Creative Commons Attribution 4.0 International License (CC BY) allows users to share and adapt with attribution, excluding materials credited to previous publications.

License: https://creativecommons.org/licenses/by/4.0/. Details: https://jnm.snmjournals.org/page/permissions.

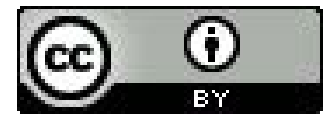




\section{ABSTRACT}

Molecular imaging techniques like positron emission tomography (PET) and single-photon emission computed tomography (SPECT) have been used to shed light on how the Corona Virus Disease 2019 (COVID-19) affects the human brain. We provide a systematic review that summarizes the current literature according to five predominant topics: 1. Few case reports suggest reversible cortical and subcortical metabolic alterations in rare cases with concomitant, para- or post-infectious encephalitis. 2. Imaging findings in single patients with first manifestations of parkinsonism in the context of COVID-19 resemble those in neurodegenerative parkinsonism (loss of nigrostriatal integrity), but scarceness of data and a lack of follow-up preclude further etiological conclusions (e.g., unmasking/hastening of neurodegeneration vs. (para-) infectious parkinsonism). 3. Several case reports and few systematic studies addressed focal symptoms and lesions, most notably hyposmia. Results are variable, although some studies found regional hypometabolism of regions related to olfaction (e.g., orbitofrontal and mesiotemporal). 4. A case series and systematic studies in inpatients with COVID-19-related encephalopathy (acute to subacute stage) consistently found a frontoparietal-dominant neocortical dysfunction (on imaging and clinically) that proved to be grossly reversible in the majority of cases until 6 months. 5. Studies in "Post-COVID-19 syndrome" provided controversial results. In patients with a high level of self-reported complaints (e.g., fatigue, memory impairment, hyposmia, dyspnea) some authors found extensive areas of limbic and subcortical hypometabolism, while others found no metabolic alterations on PET and only minor cognitive impairments (if any) on neuropsychological assessment. Furthermore, we provide a critical appraisal of studies in regard of frequent methodological issues and current pathophysiological concepts. Finally, we devised possible applications of PET and SPECT in the clinical work-up of diagnostic questions related to COVID-19. 


\section{INTRODUCTION}

Neurological complications (1) and neurocognitive aftermaths (2) are frequently described in Corona Virus Disease 2019 (COVID-19) which is caused by an infection with the severe acute respiratory syndrome coronavirus 2 (SARS-CoV-2). Neurological symptoms are present in roughly two-thirds of hospitalized COVID-19 patients, being associated with a more severe course of disease (3), higher age and preexisting comorbidities (4). So far, the most widely accepted classification of COVID-19-related symptoms refers to their timing with respect to symptom onset (5): the acute phase covers the first four weeks, whereas the terminus ongoing symptomatic COVID-19 designates the period between fifth and twelfth week after symptom

onset. Symptoms that persist for longer than twelve weeks and are not explained by an alternative diagnosis are finally subsumed as a Post-COVID-19 syndrome (also referred to as “Long-COVID syndrome").

During the acute phase of the disease, the following complications have been reported with decreasing frequency: 1 . Disturbance of smell and/or gust in approximately $60-80 \%$ of patients (6). 2. Myalgia as a sign of viral myositis in approximately $40 \%$ of patients (7). 3 . Encephalopathies with various manifestations in $15-30 \%$ of hospitalized patients $(3,8,9)$. 4 . Cerebrovascular events (e.g., stroke, hemorrhage or sinus vein thrombosis) in $1-5 \%$ of hospitalized patients (10). 5. Peripheral neuropathies ranging from cranial nerve palsies to Guillain-Barré syndrome were described in larger cases series (11,12). 6. Encephalitic manifestations have been observed only occasionally (13).

Regarding the phase of ongoing symptomatic COVID-19, various studies report lasting neuropsychiatric symptoms such as fatigue, memory loss and attentional problems $(14,15)$. Furthermore, cognitive impairment affecting attentional and executive functions, memory and visuoconstruction are ascertainable by neuropsychological test batteries (16-18). Especially in patients treated as inpatients or with more severe clinical courses, a some of these symptoms 
may represent residual, though recovering deficits from an initial COVID-19-related encephalopathy (see below).

Among other symptoms, fatigue, subjective cognitive impairment and headache extend into the phase of Post-COVID-19 syndrome $(2,19)$. Although the term "Post-COVID-19 syndrome" in its strict sense (5) is detached from particular symptoms, it is widely used as a label for a syndrome enveloping lasting fatigue, cognitive problems and shortness of breath which affect approximately $10 \%$ of all patients $(2,19)$. It is important to note that these symptoms, unlike symptoms in cases with COVID-19-related encephalopathy, do not necessarily occur with or shortly after infection, but may be noticed weeks to even months later, and affect not only initially severely affected patients but also those with a uncomplicated, ambulatory disease course $(2,19)$. Of note, during the preparation of this review, the WHO published a definition of "post COVID-19 condition" that demands, in addition to a period of usually 3 months from symptom onset, the presence of at least one specified symptom (e.g., fatigue, cognitive dysfunction), lasting for at least two months and exerting a relevant impact on everyday functioning (20). Due to the novelty of this publication, all reports reviewed here used institutional or earlier definitions (5).

Furthermore, the incidence of dementia, parkinsonism and psychiatric disorders (i.e., mood, anxiety and psychosis) within six months after infection is significantly higher in patients who suffered from COVID-19 compared to those affected by influenza or other respiratory tract infections (21). Here, encephalopathy during the acute phase turned out to be the most important risk factor. Thus, COVID-19 may unmask subclinical neurodegenerative disorders or worsen preexisting conditions.

Molecular imaging techniques such as positron emission tomography (PET) and singlephoton emission computed tomography (SPECT) have been used for the diagnostic work-up of neurological COVID-19 manifestations. These examinations provided a plethora of sometimes 
conflicting results in highly variable populations that are often ill-defined in terms of symptoms and temporal course. Thus, the objective of the present systematic review is to provide a comprehensive, structured and critical review of actual knowledge on molecular imaging in neuropsychiatric COVID-19 manifestations. In addition, we provide a preliminary suggestion on possible future use of PET and SPECT in this particular field of application based on the literature and our personal experience.

\section{MATERIALS AND METHODS}

We have conducted a MEDLINE (https://www.ncbi.nlm.nih.gov) literature search to identify peer-reviewed original studies and case series or case reports employing PET or SPECT to investigate CNS manifestations of COVID-19. The following search criteria were applied: “(corona OR COVID OR SARS-CoV-2) AND (PET OR positron OR SPECT OR singlephoton) AND (brain OR cerebral)", limited to the years 2019-2021. Titles, abstracts, full text articles and references were screened to identify appropriate reports. In addition, we conducted a selective literature search for current literature on general, neurological and psychiatric aspects of COVID-19 and related topics to embed the imaging finding into clinical and scientific context.

\section{INSIGHTS FROM MOLECULAR IMAGING WITH PET AND SPECT}

The literature search yielded 53 hits (as of November 1, 2021), of which 25 publications included the results of PET and SPECT examinations in patients with various neurological symptoms and complaints at variable time points after an infection with SARS-CoV-2. These reports comprise 15 case reports or case series (for details see Supplemental Table 1) and 10 original publications (Table 1 and 2; Supplemental Table 2). For the sake of clarity, we assorted all reports to one of the five topics listed below. Of note, according to current knowledge this 
does not imply that different mechanisms necessarily underlie each different topic and that these are mutually exclusive.

\section{Encephalitis}

There are three independent case reports including ${ }^{18} \mathrm{~F}$-fluorodeoxyglucose $\left({ }^{18} \mathrm{~F}-\mathrm{FDG}\right)$ PET in patients with autoimmune encephalitis in the acute to subacute phase of COVID-19 (2224). Given the preliminary nature of case reports, we are only summarizing the most noteworthy findings, while the interested reader is referred to Supplemental Table 1. PET showed diffuse cortical hypometabolism $(n=1)$ and increased metabolism in basal ganglia $(n=3)$, mesiotemporal structures $(n=1)$ and cerebellum $(n=1)$, possibly rated to cerebellum- and basal ganglia-specific anti-neuronal antibodies in two of these patients $(22,24)$. Interestingly, immunomodulating treatment led to improvement in all patients with a 6-months follow-up ${ }^{18} \mathrm{~F}$-FDG PET being normal in one patient (24). The authors postulated para- or post-infectious encephalitis without evidence of direct virus invasion, which fits to other relative rare cases in the literature (13).

\section{Parkinsonism and Other Neurodegenerative Diseases}

Three case reports described molecular imaging findings in four patients with first manifestations of parkinsonism occurring only weeks after SARS-CoV-2 infection (in part with other neurological symptoms like myoclonus, fluctuating consciousness, ocular abnormalities and cognitive impairment; Supplemental Table 1). Again, these findings have to be regarded preliminary, although raising the important question if and how a COVID-19-related CNS pathology may unmask and/or worsen neurodegeneration (21): Imaging of dopamine transporter availability with ${ }^{123}$ I-FPCIT SPECT $(25,26)$ and dopamine synthesis and storage with ${ }^{18}$ F-FDOPA PET (27) in three of these patients confirmed a nigrostriatal dopaminergic deficit. In one case, normal cardiac innervation as assessed by ${ }^{123}$ I-MIBG scintigraphy and subsequent improvement without specific treatment argues against incipient Parkinson's disease (PD). The 
authors speculate that SARS-CoV-2 virus may have gained access to the CNS and affected the midbrain (25). Two cases showed clinical and ${ }^{18}$ F-FDG PET findings compatible with postinfectious immune-mediated encephalitis that bears similarities to encephalitis lethargica after the influenza epidemic in 1918 (26). However, discrepant to the encephalitis cases mentioned above, these patients did not improve, neither spontaneously nor with immunomodulatory treatment, and it is unclear if this may be caused by subsequent development or unmasking and hastening of pre-clinical neurodegeneration (26). Similarly, a case reported by Cohen et al. (27) was diagnosed with probable $P D$ according to current diagnostic criteria, possibly facilitated by genetic susceptibility and/or virus-induced inflammation. To the best of our knowledge, no imaging follow-up has been published until today, which would help to unravel the underlying mechanism. Finally, the possibility that SARS-CoV-2 infection may precipitate and accelerate neurodegenerative diseases was also raised by Young et al. (28) who presented the case of a previously healthy man who developed rapidly progressive and fatal Creutzfeldt-Jakob disease (CJD) two weeks after being diagnosed with COVID-19. In line with CJD, ${ }^{18}$ F-FDG PET showed left hemispheric hypometabolism. The authors refer to animal and human studies showing that pro-inflammatory cytokines may promote neuroinflammation and progression of various neurodegenerative forms of dementia and parkinsonism (28).

\section{Focal Symptoms/Lesions:}

Olfactory dysfunction is the most frequent focal neurological sign in COVID-19 (see Introduction). Several case reports (Supplemental Table 1) and two systematic studies (Supplemental Table 2) addressed this symptom. Niesen et al. (29) prospectively examined 12 patients with ${ }^{18} \mathrm{~F}-\mathrm{FDG}$ PET/MRI about two weeks after sudden loss of smell in COVID-19. Single-subject and group analyses of ${ }^{18}$ F-FDG PET data showed no significant regional finding when using a conservative statistical threshold (i.e., $p<0.05$, family-wise error (FWE)-corrected). When using a liberal threshold $(p<0.001)$, individual analyses showed a heterogeneous pattern 
of metabolic decreases $(n=3)$, increases $(n=1)$ or both $(n=8)$ in various regions (e.g., olfactory regions, primary and higher-order cortices, cerebellum), while group analyses resulted in clusters of hypometabolism in medial and dorsal frontal areas and hypermetabolism in orbitofrontal and parietal cortex and thalamus. Given the heterogeneity of findings, the authors concluded that the main pathophysiological hypotheses of COVID-19-related hyposmia (i.e., olfactory cleft obliteration; neuroinvasion of SARS-CoV-2) do not explain dysosmia in all patients, and that the PET findings probably reflect deafferentiation and functional reorganization (29). In contrast, earlier case reports found orbitofrontal hypometabolism in patients with anosmia $(30,31)$, which was interpreted as a result of direct neuroinvasion of SARS-CoV-2 via the olfactory bulb. As preliminary support for a possible extension of impairment to other brain structures, the latter groups also reported hypometabolism of medial temporal structures in a patient with COVID-19-related parosmia (32) and a patient without olfactory dysfunction (31) (in addition to other regions; Supplemental Table 1). A recent systematic study also found hints for an impairment of mesiotemporal structures in COVID-19related olfactory dysfunction: Donegani et al. (33) prospectively recruited 14 patients with isolated hyposmia during the recovery phase from COVID-19 (4-12 weeks after first positive PCR). Compared to control subjects and applying corrections for covariates (age, sex, scanner type) and multiple comparisons (i.e., p $<0.05$ FWE-corrected), patients with isolated hyposmia were characterized by clusters of hypometabolism in the bilateral parahippocampal and fusiform gyri and the left insula, possibly reflecting cortical deafferentiation. Beyond its implication in hyposmia, the involvement of limbic regions in COVID-19 may imply a risk of developing longterm neurological (possibly cognitive) impairment, as discussed by the authors (33).

Other focal signs preliminary investigated by ${ }^{18}$ F-FDG PET include a case of facial palsy with putative hypometabolism of the respective facial nerve (34) and a patient with frequent focal seizures possibly due to subacute encephalitis after SARS-CoV-2 infection with a normal 
${ }^{18}$ F-FDG PET scan (35) (Supplemental Table 1). Another group reported hypermetabolism of the inferior colliculi as a novel finding in patients with COVID-19 $(36,37)$ that was associated with more frequent seizures and higher blood leukocytes at admission. However, the cause of this finding (e.g., inflammatory reaction (37), hyperactivation (36), artifact) and its clinical relevance needs to be defined (Supplemental Table 1 and 2).

\section{Encephalopathy}

It is important to note that all patients reported in this Encephalopathy paragraph underwent inpatient and possibly intensive care unit (ICU) treatment because of the overall high severity of COVID-19 symptoms. Furthermore, symptoms compatible with encephalopathy occurred with or briefly after onset of general COVID-19 symptoms. Thus, the following study populations comprise a fairly homogenous group. This probably constitute the basis for the observation that available ${ }^{18} \mathrm{~F}$-FDG PET studies in COVID-19-associated encephalopathy yielded very consistent results (Table 1 and Supplemental Table 1):

An initial case series by Delorme et al. ((38); $n=4)$ and subsequent systematic prospective studies by Kas et al. ((39); $n=7)$ and Hosp et al. ((18); $n=15 / 29$ with PET, exhibiting symptoms compatible with encephalopathy) unanimously showed that the acute to subacute phase ( \pm 1 months after infection) of COVID-19-associated encephalopathy is characterized by cognitive impairment (e.g., psychomotor agitation or slowing, executive functions, attention, visuoconstruction and memory) and occasional other neurological signs (e.g., hemiparesis, ataxia, apraxia, aphasia, myoclonus, seizures). This clinical presentation is accompanied by a pronounced hypometabolism of frontoparietal-dominant neocortical areas (visual reads and conventional SPM analyses, $\mathrm{p}<0.05$ FWE-corrected or $\mathrm{p}<0.01$ false-discovery rate [FDR]corrected). Very similar results were gained from a voxel-wise, principal components analysis (PCA)-based comparison to age-matched controls, which yielded an extensive pattern of negative voxel-weights (i.e., reduced metabolism) in frontoparietal-dominant neocortical areas 
and caudate nucleus (18). While an apparent hypermetabolism of striatum, pons and cerebellar structures was found on individual visual reads and in statistically liberal $(p<0.05$ uncorrected) group analyses $(18,38,39)$, more thorough analyses suggest that these regions most likely show a preserved, actually not elevated metabolism $(18,40)$. Figure 1 shows the results of PCA and SPM group comparisons of patients with COVID-19-related encephalopathy compared to a group of healthy controls. Moreover, the individual pattern expression score (PES) of the COVID-19-related spatial covariance pattern exhibited a highly significant, negative correlation with individual results from cognitive testing using the Montreal Cognitive Assessment (MoCA; $\left.r^{2}=0.62, p<0.001(18)\right)$.

Sequential follow-up data 1 month later (39) and at 5-6 months after infection $(39,41)$ demonstrate a steady, though not necessarily complete improvement of the clinical condition and ${ }^{18}$ F-FDG PET findings in the vast majority of patients: In the study by Kas et al. (39) all but one patient showed a normal neurological examination and recovered autonomy of daily living on follow-up. Still, all had abnormal cognitive evaluations with at least attentional/executive deficits and four presented with psychiatric impairments. In parallel, cerebral metabolism improved on group-level with mild residual hypometabolism of the bilateral rectal gyri, right insula, caudate nucleus and cerebellum. On a subject-level, all but one patient, who got worse, showed a moderate to almost complete improvement (39).

Blazhenets et al. (41) provided the follow-up data of 8 patients from the COVID-19 register described in Hosp et al. (18) (see Table 1 for details): In parallel to a significant improvement in MoCA performance (from $19 \pm 5$ to $23 \pm 4, p=0.03$; still below normality $(<26 / 30$ ) in $n=5 / 8)$, follow-up ${ }^{18} F-F D G$ PET examinations showed a significant recovery $(p<0.01$, FDRcorrected) of initial neocortical hypometabolism with small areas of reduced metabolism being still detectable at a liberal statistical threshold $(p<0.005)$ at 6 months. Likewise, the PES of the COVID-19-related spatial covariance pattern also significantly decreased over time $(p<0.005)$, 
albeit being still higher than in controls at trend level $(p=0.06)$. Again, the PES was inversely correlated with cognitive performance (repeated measure $r^{2}=0.39, p<0.01(41)$ ).

Aforementioned authors agreed that COVID-19-related encephalopathy and accompanying PET findings are unlikely to be caused by encephalitis due to neuroinvasion of SARS-CoV-2. Findings are more likely explained by a parainfectious systemic immune mechanism (e.g., cytokine release $(18,38,39,41))$, which according to an autopsy case in the study by Hosp et al. (18) manifests as pronounced microgliosis in white matter, while grey matter was mostly spared. Furthermore, it was suggested that an underlying neurodegenerative disease may be a predisposing factor (38), which may be particularly the case in those who do not recover.

\section{Post-COVID-19 Syndrome}

Post-COVID-19 syndrome is defined by persisting symptoms at three months after symptom onset. Thus, it may include a highly variable group of patients in terms of initial disease severity, temporal course and complaints. Patients still recovering from earlier manifestations (e.g., encephalopathy, usually treated as inpatients) may fall into this category, as will those who experience subjective complaints of "brain fog" only weeks after infection. Up to now, one preliminary case report (Supplemental Table 1) (42) and four systematic studies have been published (Table 2).

Guedj and colleagues reported two studies in adults ((43); $n=35)$ and children ((44); n=7) with persistent subjective complaints (mostly memory/cognitive complaints, fatigue, insomnia) after apparent recovery from COVID-19. The mean or median delay between COVID-19 onset and PET was three and five months in the adult and pediatric population, respectively. However, the time spans (26-155 days and 1-8 months, respectively) indicate that both studies included subjects with ongoing COVID-19 according to aforementioned definitions (5) (they would also not fulfill the novel definition of post COVID-19 condition by WHO (20)). Both studies provided 
very similar results $(p<0.05$ FWE-corrected in adults; $p<0.001$ uncorrected in children): Compared to healthy adult subjects and control pediatric patients, Long-COVID patients showed extensive areas of hypometabolism including the bilateral orbitofrontal cortex (in children only at a liberal statistical threshold), bilateral medial temporal lobes (hippocampus and amygdala; in adults only right side), right thalamus (in adults only), brainstem and cerebellum. In adults, the number of complaints showed a (weak) negative association with brainstem and cerebellum uptake $\left(r^{2}=0.1\right.$ and 0.34 , respectively). In their initial study in adults, the authors propose neurotropism of SARS-CoV-2 through olfactory bulb with extension of impairment to limbic and other aforementioned regions (43), while they provide additional alternative explanations in the latter study in children (e.g., inflammatory, dysimmune or vascular changes, disturbance of gutbrain relationship, psychological causes (44)). Sollini and colleagues (45) conducted a casecontrol study enrolling 13 patients with symptoms (mostly dyspnea, fatigue; see Table 2) persisting longer than 30 days after infections recovery (average 4.4 months) and extracted brain scan from whole-body ${ }^{18} \mathrm{~F}-\mathrm{FDG}$ PET/CT examinations. Compared to surgically-treated melanoma patients, patients with Long-COVID exhibited hypometabolism of the right parahippocampal gyrus and thalamus at a liberal statistical threshold $(p<0.001$, uncorrected). Exploratory analyses $(p<0.005$, uncorrected) linked symptoms like anosmia/ageusia or fatigue to additional regions like orbitofrontal cortex or brainstem (substantia nigra), respectively.

In contrast, Dressing et al. (46) recruited patients with neurocognitive symptoms persisting for more than three months after infection (6.6 months on average; retrospectively, all meeting the criteria of post COVID-19 condition by WHO (20)). All patients complained about attention and memory problems, the majority also about fatigue and $39 \%$ could not return to previous levels of independence/employment. However, on extensive neuropsychological testing, half of the patients were completely unimpaired, while other patients showed mild to moderate impairment in single domains (most frequently visual memory, $21 \%$ of cases). The 
most consistent finding was fatigue (61\%; cognitive fatigue $67 \%$ ) when using a self-rating questionnaire. Fourteen patients underwent ${ }^{18} \mathrm{~F}-\mathrm{FDG}$ PET that yielded no significant regional abnormality in comparison to control patients (neither on single-subject- nor group-level, using both SPM $[p<0.005$, uncorrected] and PCA; see Figure 1). No correlation between clinical variables and PET measures could be established. Given the striking discrepancy between these findings and findings in COVID-19-related encephalopathy, the authors propose that mechanisms other than those in encephalopathy probably contribute to Post-COVID-19 syndrome, foremost fatigue (46).

\section{CRITICAL APPRAISAL OF PET AND SPECT LITERATURE}

According to the WHO (https://covid19.who.int/), there have been almost 250 million confirmed COVID-19 cases and five million deaths until November 1, 2021. In parallel, an unprecedented wealth (or flood) of scientific reports on COVID-19 was published, amounting to 92,940 MEDLINE entries in 2020 and 114,360 in 2021 up to November, 1 (search term "COVID19"; >300 reports per day since January 1 2020). While there is no doubt that the COVID-19 pandemic required a fast and collective response of medical researches, it is also a frequent perception that in the early phase of the pandemic nearly everything labelled with the term "COVID-19" got quickly published, sometimes too quickly. Still, many questions await definite answers (e.g., mechanism underlying COVID-19-related CNS changes) and it is worthwhile critically gauging existing reports. For instance, a note of caution has recently been published regarding the quality of mental health research in the COVID-19 pandemic, raising concerns about the validity, generalizability and reproducibility of findings (47).

There are several recurring issues, some of which will be briefly discussed below. They should be kept in mind when considering the present results. They also represent a request and motivation for further studies: 


\section{Study Design and COVID-19 Populations}

Given the still high incidence of COVID-19, there is no necessity to rely on retrospective analysis of convenient samples. They pose an inherent risk of bias and, due to the lack or inconsistency of data, do not allow for in-depth analyses of clinicoimaging correlations (see below). Likewise, case reports or series are hardly justified except for very rare conditions, for which they may constitute an interesting starting point (see above). In addition, it is evident, that currently available longitudinal studies provided the deepest insight into underlying mechanisms and their course $(39,41)$.

The latter studies demonstrated a strong time-dependency of COVID-19-related CNS changes, which underlines the need to clearly define the time window of inclusion of patient with respect to the time of SARS-CoV-2 infection. Likewise, it is apparent that a large fraction of inpatients suffers from COVID-19 encephalopathy ( 70\% (18)), which takes several months to recover $(39,41,48)$. Despite of objective cognitive impairment in these patients, subjective perception of deficits and psychological strains are frequently lacking in this group (49). In contrast, symptoms like stress, anxiety and reduced wellbeing are more prevalent after a mild course of disease (49). Accordingly, long-term symptoms like subjective cognitive impairment and fatigue typically occur in patients characterized by young age ( $<50$ years) and low rate of hospitalization $(<30 \% ;(2,19))$. As the definition of "Post-COVID-19 syndrome" used so far only reflects temporal aspects (5), there is a tremendous risk to build mixed populations in terms of initial disease severity, treatment and impairment (subjective/objective). Proper selection of patients will be key to separate protracted COVID-19-related encephalopathy from the PostCOVID-19 syndrome in a strict sense $(2,19)$. In this respect, the novel, stricter WHO definition is a welcome progress (20). In fact, available PET studies do not support the idea that neurocognitive Post-COVID-19 syndrome represents a protracted manifestation of COVID-19related encephalopathy, because available studies in Long-COVID or Post-COVID-19 syndrome 
either yielded no metabolic alteration at all (46) or depicted metabolic changes (43-45) that do not match the highly consistent findings in COVID-19-related encephalopathy $(18,39)$. Concerning the diagnosis of COVID-19, a PCR or at least state-of-the-art antibody proof should be mandatory. From a clinical perspective, typical clinical findings may be sufficient to ground a diagnosis in a pandemic situation, but this is not sufficient for a scientific study trying to unravel a specific disease.

Up to now, none of the reviewed studies conducted a proper sample size calculation. Likewise, study registration appears to be an exception (e.g., $(18,46))$ that needs to be turned into a rule.

\section{Control Populations}

The use of convenient samples seems to be an even bigger problem when it comes to PET reference data sets. In fact, the descriptions of methods of most studies do not clearly state if reference populations were indeed examined under comparably circumstances (e.g., identical scanner, acquisition, reconstruction, preparation, etc.). The contribution of technical differences may be negligible if disease effects are large, but this may be a crucially biasing factor if effects are small (e.g., Post-COVID-19 syndrome). Some authors acknowledge inconsistencies and conducted confirmatory analyses (18), while most authors ignored this issue. The use of oncological control patients may be particularly problematic, if brain scans are cropped out of a whole-body scans that are usually acquired and reconstructed differently than brain scans. Furthermore, preparation of brain scans require well-defined resting (or neutral) conditions, while adherence to this is lower in patients undergoing whole-body PET/CT (patients may read, talk or use their smartphones).

Since the publication of the original studies by our group relying on control patients (i.e., unclear neurological or psychiatric complaints, in whom a somatic CNS disease was carefully excluded $(18,41,46))$, we had the opportunity to scan a cohort of thoroughly evaluated healthy 
controls. The local ethics commission and federal office for radiation protection approved this study and all subjects signed a written informed consent. Using these subjects as reference cohort, we were able to confirm our initial results (Figure 1). We also conducted an additional analysis in subjects with Post-COVID-19 syndrome and hyposmia, but we found no significant hypometabolism of olfactory regions as suggested by other groups.

\section{PET Data Analysis}

Comparison of datasets by common statistical methods like SPM requires count rate or intensity normalization. It is well known that extensive, disease-related metabolic alterations in one direction may cause artificial alterations in the other direction on conventional analyses, if diseased brain regions are part of those used for normalization. In case of neocortical hypometabolism and normalization by whole-brain proportional scaling, apparently "hypermetabolic" areas often include the basal ganglia, thalamus, mesiotemporal regions, brainstem and cerebellum (40). Several lines of evidence like ROI analyses (plasma glucosecorrected uptake values), clinicoimaging correlations and follow-up studies suggest that aforementioned areas of hypometabolism in subacute settings most likely reflect true hypometabolism (40). However, in the opinion of the authors and with possible exception of concomitant autoimmune encephalitis, it is still questionable if regions of hypermetabolism reported in several studies exhibit true hypermetabolism or inflammation. On one hand, the latter is not convincingly supported by histopathological data (see below). On the other, an artificial increase seems much more likely, especially if global count rate normalization was applied (40). Still, given the systemic activation of microglia and astrocytes (albeit being most pronounced in brainstem and cerebellum; see below), one cannot exclude that associated metabolic changes cause some bias if white matter is used a reference region $(18,41)$. One way to avoid this problem may be to conduct PCA-based analyses as proposed by Hosp et al. (18). 
Given the complexity, costs and radiation exposure, cohorts in PET studies are often rather small, which limits their statistical power. Thus, a pragmatic approach may be to define liberal statistical threshold and avoid a correction for multiple comparisons. This may lead to type I errors. It is noteworthy that several systematic studies (Table 1 and 2, Supplemental Table 2) used liberal thresholds and, consequently, that this limitation needs to be kept in mind when considering anatomically (e.g., small clusters located close or within CSF spaces; (45)) or functionally (e.g., weak correlations with subjective, ill-defined complaints; (43)) questionable findings. Aforementioned limitations particularly apply to case reports or smaller series, which often suffer from additional flaws (e.g., reliance on observer-dependent visual reads, lack of coregistration to high-resolution structural imaging/MRl; see Supplemental Table 1).

\section{Clinicoimaging Correlations}

Whereas clinicoimaging correlations cannot prove causality, they may be very useful to check for plausibility. For instance, the high correlation of frontoparietal-dominant changes of cerebral metabolism and formally assessed cognitive functions served by frontoparietal regions in COVID-19 encephalopathy (18) supports the notion that these changes depend on each other. The magnitude of metabolic alterations was also in line with imaging studies in patients with comparable cognitive deficits (e.g., dementia).

In turn, some imaging findings need further elucidation: For instance, bilateral hyperactivation of the inferior colliculi $(36,37)$ may be expected to interfere with normal auditory functioning, which, however, was not reported. Given that this finding was reported in rather severely affected patients, one may also consider alternative explanations (e.g., artificial, relative "hypermetabolism" due to neocortical hypometabolism). Donegani et al. (33) reported a bilateral hypometabolism of the parahippocampal and fusiform gyri in isolated hyposmia. Although they used an 8-item odor test, no correlation analyses were reported. In turn, one may also have expected other deficits like memory impairment, which unfortunately was not 
addressed. In case of Post-COVID-19 syndrome, the situation is even more complex: Patients commonly complain about multiple symptoms (see above) with high impact on daily functioning, which, however, cannot be verified in such magnitude by formal testing $(46,49)$. Still, extensive patterns of hypometabolism have been reported $(43,44)$, which on first glance may be expected to result in various additional symptoms (e.g., severe objective amnestic problems). Unfortunately, no formal testing was pursued. In contrast, no such metabolic changes were observed in the aforementioned study by Dressing et al. (46), which underscores the need to verify symptoms and complaints by operationalized formal assessments to gain deeper insights and unravel discrepancies. The latter will also benefit from inclusion of additional correlative biomarkers (e.g., PET or CSF biomarkers of neurodegeneration) and, ultimately, imagingneuropathology correlations which are still very sparse (18).

\section{Correlations with Knowledge from Related Disciplines}

Imaging findings and concepts derived thereof have to be aligned with knowledge from related disciplines. It is evident that neurological or neurocognitive findings in COVID-19 cover a broad spectrum of disciplines. Neuropathological findings and psychiatric concepts may be considered as two distant ends of such a spectrum. However, we believe that these disciplines are particularly helpful for a better understanding of current findings.

Insights from Neuropathological Studies. Whereas an early neuropathological investigation of patients who died from COVID-19 primarily found hypoxic damage (50), more recent reports draw a vivid picture on how COVID-19 may affect the CNS $(51,52)$. Major findings include an activation of microglia (formation of microglia nodules in some patients) and astrocytes that was pronounced in brainstem and cerebellum and affected white rather than grey matter. Detection of SARS-CoV-2 (spike protein and/or RNA) succeeded in approximately $50 \%$ of patients, especially in brain stem and cranial nerves. This is remarkable, as the neuroinvasive potential of betacoronaviruses has been broadly discussed (e.g., after nasal inoculation, with axonal and 
transsynaptic propagation) (53,54). However, due to its sparse detection rate in neuropathological samples and due to the absence of lytic figures, infected neurons or glial cells (51), proofs for direct neuroinvasivity and the occurrence of neuron to neuron propagation within the human CNS are lacking. Regarding adaptive immunity, infiltration of CD8 and CD4 T cells especially occurred in the perivascular compartment, being associated with blood-brain-barrier dysfunction. Interestingly, the immune activation within the perivascular compartment is specific for COVID-19 and differed from findings in patients with multiple sclerosis or non-COVID-19 respiratory failure (52). Although SARS-CoV-2 spike-protein has been occasionally detected in perivascular cells (52), neuroinflammatory changes are more likely induced by circulating cytokines and inflammatory mediators in the course of a systemic inflammatory response $(51,55)$. It has to be emphasized that aforementioned data were derived from unselected patient populations, as the presence of neurological symptoms was not registered. Thus, additional studies with detailed clinicopathological correlations are warranted. In addition, PET imaging of activated microglia might represent a promising imaging technique in COVID-19, but to the best of our knowledge has not been explored yet.

Current Concepts of Fatigue. Fatigue might be translated as "extreme and persistent tiredness, weakness or exhaustion that could be mental, physical or both" (56), but there is no further agreement upon definition of this entity (57). Fatigue can co-occur with clinical symptoms such as depression, pain, sleep impairment, and cognitive dysfunction (58) and can be associated with chronic medical conditions (e.g., post-viral infection, cancer, inflammatory bowel disease, multiple sclerosis, depression, fibromyalgia (59)). Thus, a multi-factorial etiology with strong impact of somatic as well as psychosocial risk factors has been postulated (60). As illustrated above, fatigue has a significant symptom overlap and comorbidity with psychiatric disorders (61). This is in line with a study investigating predictors of fatigue in individuals recovering from the acute phase of COVID-19: While female gender and a comorbidity of 
depression or anxiety were identified as significant predictors for developing fatigue, indicators of COVID-19 severity, markers of peripheral immune activation and circulating pro-inflammatory cytokines did not reach statistical significance (62). Still, fatigue seems to be distinct from psychiatric disorders, however, perceptions, attributions and coping skills of patients suffering from psychiatric comorbidity may perpetuate the fatigue condition (61). This notion is reinforced by a significant therapeutic response of fatigue to cognitive behavior therapy (63). As far as permissible and based on the rather disappointing experience with ${ }^{18} \mathrm{~F}$-FDG PET in psychiatric and somatoform disorders, one may expect that the contribution of ${ }^{18} \mathrm{~F}$-FDG PET to understand and diagnose a Post-COVID-19 syndrome dominated by fatigue is actually limited.

\section{PERSONAL PERSPECTIVE: USE OF MOLECULAR IMAGING IN COVID-19- RELATED CNS DISORDERS}

From a scientific point of view, molecular imaging of COVID-19-related CNS disorders represents an exciting field that not only contributes to the understanding of disease mechanisms in COVID-19 but may also provide important implications for other conditions (e.g., neurodegeneration, encephalopathies, delirium). In this regard, we believe that carefully designed studies in COVID-19 populations are of great interest.

Concerning the clinical application of molecular imaging for diagnosis and management of COVID-19-related CNS disorders, we actually see little impact and, consequently, little need to adjust current clinical practice: ${ }^{18} \mathrm{~F}-\mathrm{FDG}$ PET is gaining increasing acceptance for (differential) diagnosis and follow-up of encephalitis, often showing superior performance over MRI (e.g., $(64,65))$. Even more so, PET and SPECT are established methods for (differential) diagnosis of neurodegenerative CNS disorders like parkinsonism (e.g., (66,67)). Accordingly, in patients with suspected encephalitis or parkinsonism in the context of COVID-19, PET and SPECT may be performed according to established clinical pathways. Follow-up studies would in fact be of particular interest for differentiating between possible reversible COVID-associated nigrostriatal 
dysfunction and progressive, presumably COVID-independent neurodegenerative parkinsonism. Molecular imaging is also accepted for differential diagnosis in cognitive impairment and dementia (e.g., (68)). However, in the context of COVID-19, it is probably advisable to define the need for additional imaging studies based on the clinical presentation and time course. In case of possible COVID-19 encephalopathy, a reversible cortical dysfunction can be assumed. Whilst in Post-COVID-19 syndrome with predominant fatigue and without decisive pathological findings on neuropsychological testing, a pathological imaging correlate is actually unlikely. In our opinion, patients with (subjective) neuropsychiatric deficits as potential sequelae of COVID-19 should undergo a comprehensive clinical work-up including validated neuropsychological and neuropsychiatric testing to verify deficits. A diagnostic benefit from ${ }^{18} \mathrm{~F}-\mathrm{FDG}$ PET may only be expected if a cognitive impairment is verified and persisting ( $>3-6$ months) or progressive. 


\section{TABLES}

Table 1: Systematic studies on molecular imaging in cerebral manifestations of COVID-19: Encephalopathy

\begin{tabular}{|c|c|c|c|c|c|c|c|c|}
\hline \multirow[t]{2}{*}{ Report } & \multirow{2}{*}{$\begin{array}{l}\text { Research } \\
\text { Question }\end{array}$} & \multicolumn{3}{|l|}{ Population } & \multicolumn{3}{|l|}{${ }^{18} \mathrm{~F}-\mathrm{FDG}$ PET } & \multirow[t]{2}{*}{ Hypothesis } \\
\hline & & Inclusion (main) & $\begin{array}{l}\mathrm{N} \\
\text { age }\end{array}$ & $\begin{array}{l}\text { Clinical Findings } \\
\text { (selected) }\end{array}$ & Analysis & $\Delta \mathrm{t}$ & Major Findings & \\
\hline \multirow[t]{3}{*}{$\begin{array}{l}\text { Kas et al. } \\
(2021) \\
(39)\end{array}$} & \multirow[t]{3}{*}{$\begin{array}{l}\text { longitudinal } \\
\text { metabolic } \\
\text { pattern in } \\
\text { COVID-19 } \\
\text { encephalo } \\
\text { pathy }\end{array}$} & \multirow{3}{*}{$\begin{array}{l}\text { - PCR+ } \\
\text { - new cognitive } \\
\text { impairment with } \\
\text { focal CNS sign or } \\
\text { seizure } \\
\text { o other infectious } \\
\text { or autoimmune } \\
\text { disorders } \\
\text { excluded }\end{array}$} & \multirow[t]{3}{*}{$\begin{array}{l}7 \\
50-72 \\
\text { yo. }\end{array}$} & \multirow{3}{*}{$\begin{array}{l}\text { - all hospitalized (7) } \\
\text { - ventilated (3) } \\
\text { - executive deficit, } \\
\text { frontal lobe changes } \\
\text { (7), psychiatric } \\
\text { manifestation (5) } \\
\text { ofollow-up: improved } \\
(6), \text { but residual } \\
\text { attention/executive } \\
\text { deficit at 4-8 mo., } \\
\text { anxiety/ depression (4), } \\
\text { deterioration (1) }\end{array}$} & \multirow{3}{*}{$\begin{array}{l}\circ \text { ROI } \\
\text { SPM: single- } \\
\text { subject \& group } \\
\text { onormalization: } \\
\text { scaling to pons } \\
\text { - comparison: } 32 \\
\text { NC (identical } \\
\text { protocol) } \\
\circ p<0.05 \mathrm{FWE}\end{array}$} & - acute & $\begin{array}{l}\circ \text { DEC: frontal, insula, cingulate, } \\
\text { CN (group) and posterior cortices } \\
(6 / 7) \\
\text { - INC: vermis, dentate nucleus, } \\
\text { pons (group; } p<0.05 \text {, uncorrected) }\end{array}$ & \multirow{3}{*}{$\begin{array}{l}\text { widespread, } \\
\text { frontal dominant } \\
\text { impairment, } \\
\text { variably reversible } \\
\text { in most patients } \\
\text { until } 6 \text { months; } \\
\text { due to para- or } \\
\text { post-infectious } \\
\text { immune mecha- } \\
\text { nism }\end{array}$} \\
\hline & & & & & & $\begin{array}{l}\circ 4 \mathrm{wk} . \\
\text { later }\end{array}$ & $\begin{array}{l}\circ \text { DEC: frontal (see above), but } \\
\text { improved (group) }\end{array}$ & \\
\hline & & & & & & $\begin{array}{l}\circ 26 \\
\text { wk. } \\
\text { after } \\
\text { onset }\end{array}$ & $\begin{array}{l}\text { o almost normal, residual DEC } \\
\text { orbitofrontal, insula, cingulate, CN } \\
\text { (group); almost normal (3/7), } \\
\text { frontal (3/7), improve/decline }(1 / 7)\end{array}$ & \\
\hline $\begin{array}{l}\text { Hosp et al. } \\
(2021) \\
(18)\end{array}$ & $\begin{array}{l}\text { neuronal } \\
\text { correlates } \\
\text { of neuro- } \\
\text { logical and } \\
\text { cognitive } \\
\text { symptoms } \\
\text { (subacute } \\
\text { stage) }\end{array}$ & $\begin{array}{l}\circ \mathrm{PCR}+ \\
\circ \text { only inpatients } \\
\circ \geq 1 \text { new neuro- } \\
\text { logical symptom } \\
\text { (incl. cognition } \\
\text { [MoCA]) }\end{array}$ & $\begin{array}{l}15 \\
(\mathrm{PET})\end{array}$ & $\begin{array}{l}\text { - initial ICU (7/29; } 2 \\
\text { only observation; } 2 \\
\text { non-invasive and } 2 \\
\text { invasive ventilation) } \\
\text { - impaired gustation } \\
(29 / 29) \text { and smell } \\
(25 / 29)\end{array}$ & $\begin{array}{l}\text { - single-case: } \\
\text { visual inspection } \\
\text { - PCA (scaled } \\
\text { subprofile model) } \\
\text { - comparison: } 45 \\
\text { control pts. (iden- } \\
\text { tical protocol) }\end{array}$ & $\begin{array}{l}4 \pm 2 \\
w k\end{array}$ & $\begin{array}{l}\text { - single-case: predominant } \\
\text { frontoparietal cortical DEC } \\
(10 / 15) \text {, relative INC of striatum } \\
(3 / 15) \text { and vermis }(1 / 15) \\
\text { o group PCA: negative voxel- } \\
\text { weights (DEC) in extensive } \\
\text { neocortical regions (esp. }\end{array}$ & $\begin{array}{l}\text { cortical dys- } \\
\text { function due to an } \\
\text { inflammatory } \\
\text { process trigged by } \\
\text { systemic immune } \\
\text { response (e.g., } \\
\text { cytokine release), } \\
\text { particularly }\end{array}$ \\
\hline
\end{tabular}




\begin{tabular}{|c|c|c|c|c|c|c|c|c|}
\hline \multirow[t]{2}{*}{ Report } & \multirow{2}{*}{$\begin{array}{l}\text { Research } \\
\text { Question }\end{array}$} & \multicolumn{3}{|l|}{ Population } & \multicolumn{3}{|l|}{${ }^{18}$ F-FDG PET } & \multirow[t]{2}{*}{ Hypothesis } \\
\hline & & Inclusion (main) & $\begin{array}{l}\mathrm{N} \\
\text { age }\end{array}$ & $\begin{array}{l}\text { Clinical Findings } \\
\text { (selected) }\end{array}$ & Analysis & $\Delta \mathrm{t}$ & Major Findings & \\
\hline & & $\begin{array}{l}\circ \mathrm{PET}, \mathrm{MRI} \text { and } \\
\text { neuropsychologic } \\
\text { al test battery if } \geq \\
2 \text { new symptoms }\end{array}$ & & $\begin{array}{l}\text { - impaired cognition } \\
(\text { MoCA<26; 18/26) } \\
\text { o prominent deficits in } \\
\text { memory }(7 / 14) \text {, execu- } \\
\text { tive functions }(6 / 13) \\
\text { and attention }(6 / 15) \\
\text { - MRI mircoembolic } \\
\text { infarcts }(4 / 13) \\
\text { - CSF: PCR- }(4 / 29)\end{array}$ & $\begin{array}{l}\text { - plasma glucose- } \\
\text { adjusted SUV } \\
\text { - confirmatory } \\
\text { analyses (i) with } \\
\text { SPM (normali- } \\
\text { zation: white } \\
\text { matter, p<0.01 } \\
\text { FDR) and (ii) PCA } \\
\text { with } 35 \text { NC } \\
\text { (similar scanner) }\end{array}$ & & $\begin{array}{l}\text { frontoparietal) and CN; positive } \\
\text { voxel-weights (interpreted as } \\
\text { preserved metabolism) in } \\
\text { brainstem, CBL, MTL and white } \\
\text { matter } \\
\text { - confirmatory analyses: very } \\
\text { similar results } \\
\text { - significant negative correlation } \\
\left.\text { ( }{ }^{2}=0.62\right) \text { MoCA vs. pattern } \\
\text { expression score }\end{array}$ & $\begin{array}{l}\text { affecting white } \\
\text { matter and being } \\
\text { possibly reversible }\end{array}$ \\
\hline $\begin{array}{l}\text { Blazhenets } \\
\text { et al. } \\
(2021) \\
(41)\end{array}$ & $\begin{array}{l}\text { recovery of } \\
\text { cognitive } \\
\text { impairment } \\
\text { \& regional } \\
\text { hypometa- } \\
\text { bolism in } \\
\text { subacute } \\
\text { COVID-19 } \\
\text { during 5-6- } \\
\text { mo. follow- } \\
\text { up }\end{array}$ & $\begin{array}{l}\text { - follow-up data of } \\
\text { Hosp et al. (2021) } \\
\text { (see above) } \\
\text { - clinical register, } \\
17 \text { pts. with PET } \\
\text { during subacute } \\
\text { phase } \\
\text { } 9 \text { pts. without } \\
\text { complaints } \\
\text { refused follow-up } \\
\text { PET }\end{array}$ & $\begin{array}{l}8 \\
66 \pm 14 \\
\text { yo. }\end{array}$ & $\begin{array}{l}\text { - all treated as } \\
\text { inpatients during acute } \\
\text { phase, ICU (2) } \\
\text { - self-reported } \\
\text { persistent cognitive } \\
\text { deficits (4) } \\
\text { - MoCA: recovery from } \\
19 \pm 5 \text { (1 st) to } 23 \pm 4 \text { ( } 2^{\text {nd }} \\
\text { examination), still } \\
\text { impaired (5; esp. } \\
\text { memory) }\end{array}$ & $\begin{array}{l}\text { - PCA: expression } \\
\text { of the previously } \\
\text { established } \\
\text { COVID-19-related } \\
\text { covariance pattern } \\
\text { - SPM: paired } \\
\text { (within pts.) and } \\
\text { unpaired (vs. } \\
\text { controls pts.) } \\
\text { (see above, Hosp } \\
\text { et al., 2021) }\end{array}$ & $\begin{array}{l}23 \pm 7 \\
w k .\end{array}$ & $\begin{array}{l}\circ \text { PCA: pattern expression } \\
\text { decreased }(p=0.002) \text {, but still at } \\
\text { trend level higher than in controls } \\
(p=0.06) \\
\left.\text { o negative correlation ( } r^{2}=0.39\right) \\
\text { between MoCA and pattern } \\
\text { expression } \\
\text {-SPM (paired): significant } \\
\text { recovery of neocortical DEC } \\
\text { ( } p<0.01 \text { FDR) } \\
\text {-SPM (unpaired): residual } \\
\text { neocortical DEC (trend-level, } \\
\text { p<0.005 uncorrected) }\end{array}$ & $\begin{array}{l}\text { slow, but evident } \\
\text { reversibility of } \\
\text { lasting cortical } \\
\text { dysfunction due to } \\
\text { subcortical } \\
\text { perinflammatory } \\
\text { processes } \\
\text { (triggered by } \\
\text { systemic inflam- } \\
\text { matory response } \\
\text { or cytokine } \\
\text { release) }\end{array}$ \\
\hline
\end{tabular}


Abbreviations: PET, positron emission tomography; ${ }^{18} \mathrm{~F}-\mathrm{FDG}, 2$-deoxy-2-18 F-fluoroglucose (target parameter: glucose metabolism); CT, computed tomography, MRI, magnetic resonance imaging; COVID-19, coronavirus disease 2019; SARS-CoV-2, severe acute respiratory syndrome coronavirus 2; $\mathrm{N}$, number of patients, numbers in parenthesis refer to number of subjects with specified finding (if the subsample assessed is smaller than study group, sample size as indicated); pts., patients; $\Delta \mathrm{t}$, time interval between symptom onset or positive polymerase chain reaction (PCR+) for SARS-CoV-2 (as available) and PET; CSF, cerebrospinal fluid; MoCA, Montreal Cognitive Assessment; d, day; wk., week; mo., month; yo., years-old; ROI, region of interest analysis; SPM, statistical parametric mapping; SPM: single-subject and/or group, SPM group and/or single-subject analyses (usually COVID patient(s) vs. controls); normalization, method/reference region used for count rate normalization of PET scans; FWE, family-wise error correction; FDR, false-discovery rate correction; PCA, principal components analysis; SUV, standardized uptake value; NC, normal controls; INC and DEC, increased and decreased signal, respectively; It./rt., left/right; CN, caudate nucleus; CBL, cerebellum; MTL, mesial temporal lobe; 
Table 2: Systematic studies on molecular imaging in cerebral manifestations of COVID-19: Post-COVID-19 syndrome

\begin{tabular}{|c|c|c|c|c|c|c|c|c|}
\hline \multirow[t]{2}{*}{ Report } & \multirow{2}{*}{$\begin{array}{l}\text { Research } \\
\text { Question }\end{array}$} & \multicolumn{3}{|l|}{ Population } & \multicolumn{3}{|l|}{${ }^{18}$ F-FDG PET } & \multirow[t]{2}{*}{ Hypothesis } \\
\hline & & Inclusion (main) & $\begin{array}{l}\mathrm{N} \\
\text { age }\end{array}$ & $\begin{array}{l}\text { Clinical Findings } \\
\text { (selected) }\end{array}$ & Analysis & $\Delta \mathrm{t}$ & Major Findings & \\
\hline $\begin{array}{l}\text { Guedj et al. } \\
(2021) \\
(43)\end{array}$ & $\begin{array}{l}\text { metabolic } \\
\text { pattern of } \\
\text { long- } \\
\text { COVID }\end{array}$ & $\begin{array}{l}\text { - retrospective } \\
\text { - }>3 \text { weeks after } \\
\text { SARS-CoV-2 infection } \\
\text { (PCR+ or antibody- } \\
\text { positive) } \\
\text { - persistent fatigue } \\
\text { - PET for neuro- } \\
\text { logical complaints } \\
\text { - normal CT/MRI }\end{array}$ & $\begin{array}{l}55 \pm 11 \\
\text { yo. }\end{array}$ & $\begin{array}{l}\text { - hospitalized in ICU } \\
(12 / 31) \\
\text { - ventilated (5/31) } \\
\text { - memory/cognitive } \\
\text { complaints (17), insom- } \\
\text { nia (16), hyposmia (10) }\end{array}$ & $\begin{array}{l}\text {-SPM: group } \\
\text { o normalization: } \\
\text { proportional scaling } \\
\text { o comparison: } 44 \mathrm{NC} \\
\text { (earlier study) } \\
\text { - } p<0.001 \text {, cluster- } \\
\text { wise } p<0.05 \mathrm{FWE}\end{array}$ & $\begin{array}{l}14 \pm 4 \\
(4-22) \\
w k .\end{array}$ & $\begin{array}{l}\circ \text { DEC: rectal/orbital } \\
\text { gyrus, rt. temporal lobe } \\
\text { (incl. MTL), rt. thalamus, } \\
\text { pons/medulla, CBL } \\
\text { - various weak } \\
\left.\text { correlations ( }{ }^{2}<0.35\right) \text {, } \\
\text { e.g.: complaints (n), } \\
\text { hyposmia, memory/ } \\
\text { cognitive complaint vs. } \\
\text { CBL DEC }\end{array}$ & $\begin{array}{l}\text { SARS-CoV-2 } \\
\text { neurotropism } \\
\text { through olfactory } \\
\text { bulb, extension of } \\
\text { impairment to } \\
\text { (para-) limbic } \\
\text { regions, thalamus, } \\
\text { CBL and brain } \\
\text { stem }\end{array}$ \\
\hline $\begin{array}{l}\text { Sollini et al. } \\
(2021) \\
(45)\end{array}$ & $\begin{array}{l}\text { whole- } \\
\text { body PET/ } \\
\text { CT (incl. } \\
\text { brain) to } \\
\text { gain } \\
\text { insights } \\
\text { into long } \\
\text { COVID } \\
\text { (for whole- } \\
\text { body see } \\
\text { report) }\end{array}$ & $\begin{array}{l}\circ \text { observational case- } \\
\text { control study } \\
\circ \geq 1 \text { persistent } \\
\text { symptom for }>30 \mathrm{~d} \\
\text { after infection (PCR: } \\
\text { n.a.) } \\
\text { ॰ controls: age- \& sex- } \\
\text { matched, surgically } \\
\text { treated melanoma pts. } \\
\text { w/ neg. PET/CT。 }\end{array}$ & $\begin{array}{l}54 \\
(46-80) \\
\text { уо. }\end{array}$ & $\begin{array}{l}\text { - hospitalization (7/13) } \\
\text { - ventilated (2/13) } \\
\text { - dyspnea (9), fatigue (8), } \\
\text { anosmia (4), aguesia (3) }\end{array}$ & $\begin{array}{l}\text { - brain PET extracted } \\
\text { from whole-body } \\
\text { scans } \\
\text { - SPM: group } \\
\text { o normalization: } \\
\text { proportional scaling } \\
\text { (global) } \\
\text { - comparison: } 26 \\
\text { control pts. } \\
\text { - p<0.001 / } 0.005 \\
\text { (uncorrected) }\end{array}$ & $\begin{array}{l}19 \pm 4 \\
w k\end{array}$ & $\begin{array}{l}\circ \text { DEC (group contrast, } \\
\mathrm{p}<0.001)^{*} \text { : rt. parahippo- } \\
\text { campal, rt. thalamus } \\
\text {-DEC in persistent } \\
\text { anosmia/ aguesia } \\
(p<0.005)^{\star} \text { : bilateral } \\
\text { parahippocampal and } \\
\text { orbitofrontal } \\
\text {-DEC in persistent } \\
\text { fatigue (p<0.005)*: rt. } \\
\text { parahippocampal, } \\
\text { brainstem, bilateral }\end{array}$ & $\begin{array}{l}\text { neuronal/synaptic } \\
\text { dysfunction, } \\
\text { occurring after } \\
\text { inflammatory } \\
\text { changes triggered } \\
\text { by SARS-CoV-2 } \\
\text { infection }\end{array}$ \\
\hline
\end{tabular}




\begin{tabular}{|c|c|c|c|c|c|c|c|c|}
\hline \multirow[t]{2}{*}{ Report } & \multirow{2}{*}{$\begin{array}{l}\text { Research } \\
\text { Question }\end{array}$} & \multicolumn{3}{|l|}{ Population } & \multicolumn{3}{|l|}{${ }^{18}$ F-FDG PET } & \multirow[t]{2}{*}{ Hypothesis } \\
\hline & & Inclusion (main) & $\begin{array}{l}\mathrm{N} \\
\text { age }\end{array}$ & $\begin{array}{l}\text { Clinical Findings } \\
\text { (selected) }\end{array}$ & Analysis & $\Delta \mathrm{t}$ & Major Findings & \\
\hline & & & & & & & thalamus & \\
\hline $\begin{array}{l}\text { Morand et } \\
\text { al. (2021) } \\
(44)\end{array}$ & $\begin{array}{l}\text { regional } \\
\text { metabolic } \\
\text { pattern in } \\
\text { pediatric } \\
\text { patients } \\
\text { with sus- } \\
\text { pected } \\
\text { long } \\
\text { COVID }\end{array}$ & $\begin{array}{l}\text { - retrospective } \\
\text { - children with } \\
\text { suspected long } \\
\text { COVID (clinical } \\
\text { diagnosis) } \\
\text { - evaluation for } \\
\text { various functional } \\
\text { complaints } \geq 4 \text { wk. } \\
\text { after suspected } \\
\text { SARS-CoV-2 infection }\end{array}$ & $\begin{array}{l}12 \\
(10-13) \\
\text { yo. }\end{array}$ & $\begin{array}{l}\text { - initial symptoms: fever } \\
\text { (6), muscle pain (6), } \\
\text { asthenia (5), rhinitis (5), } \\
\text { hyposmia (5) } \\
\text { - long COVID symp- } \\
\text { toms: fatigue (5), cog- } \\
\text { nitive impairment (5), } \\
\text { dyspnea (4), headache } \\
(4) \\
\text {-PCR+ (1/5) and pos. } \\
\text { SARS-CoV-2 serology } \\
(2 / 6)\end{array}$ & $\begin{array}{l}\text { - SPM: group } \\
\text { o normalization: } \\
\text { proportional scaling } \\
\text { (global) } \\
\text { - comparison: } 21 \\
\text { pediatric control pts.; } \\
\text { findings in adults } \\
\text { (Guedj et al., 2020) } \\
\text { - p<0.001, cluster- } \\
\text { wise } p<0.05 \text { FEW }\end{array}$ & $\begin{array}{l}20(4- \\
34) w k\end{array}$ & $\begin{array}{l}\text { - comparison to pediatric } \\
\text { control pts.: bilateral } \\
\text { DEC in MTL, pons, CBL } \\
\text { ' comparison to adult } \\
\text { long COVID pts.: no } \\
\text { difference }\end{array}$ & $\begin{array}{l}\text { several possible } \\
\text { explanations } \\
\text { (inflammatory, } \\
\text { immune, neurotro- } \\
\text { pism, vascular, } \\
\text { gut-brain distur- } \\
\text { bance, psycho- } \\
\text { logical), but none } \\
\text { clearly favored }\end{array}$ \\
\hline $\begin{array}{l}\text { Dressing et } \\
\text { al. (2021) } \\
(46)\end{array}$ & $\begin{array}{l}\text { regional } \\
\text { metabolic } \\
\text { pattern in } \\
\text { patients } \\
\text { with neuro- } \\
\text { cognitive } \\
\text { long } \\
\text { COVID }\end{array}$ & $\begin{array}{l}\text { - history of PCR+ } \\
\text { SARS-CoV-2 infection } \\
\text { - new subjective } \\
\text { neurocognitive } \\
\text { symptoms }>3 \text { mo } \\
\text { since PCR }+ \\
\text { - no preexisting } \\
\text { neurodegenerative } \\
\text { disease }\end{array}$ & $\begin{array}{l}31 \\
14 \\
(\text { PET) } \\
56 \pm 7 \\
\text { yo. }\end{array}$ & $\begin{array}{l}\text { - during acute phase } \\
\text { inpatients (10; ICU } 4) \\
\text { - no current focal sign } \\
\text { - subjective difficulties in } \\
\text { attention and memo-ry } \\
\text { (31), fatigue (24), } \\
\text { reduced work quota/ } \\
\text { unable to work (12) } \\
\text { - extensive neuropsy- }\end{array}$ & $\begin{array}{l}\text { - single-case: visual } \\
\text { inspection plus } \\
\text { Neurostat } \\
\text {-PCA: expression of } \\
\text { COVID-19-related } \\
\text { covariance pattern } \\
\text { - SPM (confirmatory): } \\
\text { group, normalization: } \\
\text { brain parenchyma, } \\
\text { p<0.05 FDR }\end{array}$ & $\begin{array}{l}28 \pm 9 \\
w k\end{array}$ & $\begin{array}{l}\text { - single-case: no distinct } \\
\text { pathological finding } \\
\text {-PCA: no elevated } \\
\text { expression of the } \\
\text { COVID-19-related } \\
\text { covariance pattern, no } \\
\text { correlation with MoCA } \\
\text {-SPM (confirmatory): no } \\
\text { region of significantly } \\
\text { different metabolism, no }\end{array}$ & $\begin{array}{l}\text { other factors than } \\
\text { those causing } \\
\text { subacute cortical } \\
\text { dysfunction in } \\
\text { COVID-19 } \\
\text { cause/contribute } \\
\text { to symptoms in } \\
\text { long COVID, in } \\
\text { particular fatigue }\end{array}$ \\
\hline
\end{tabular}




\begin{tabular}{|c|c|c|c|c|c|c|c|c|}
\hline \multirow[t]{2}{*}{ Report } & \multirow{2}{*}{$\begin{array}{l}\text { Research } \\
\text { Question }\end{array}$} & \multicolumn{3}{|l|}{ Population } & \multicolumn{3}{|l|}{${ }^{18}$ F-FDG PET } & \multirow[t]{2}{*}{ Hypothesis } \\
\hline & & Inclusion (main) & $\begin{array}{l}\mathrm{N} \\
\text { age }\end{array}$ & $\begin{array}{l}\text { Clinical Findings } \\
\text { (selected) }\end{array}$ & Analysis & $\Delta \mathrm{t}$ & Major Findings & \\
\hline & & $\begin{array}{l}\text { - PET recommended } \\
\text { to all pts. (performed } \\
\text { in } 14 / 31 \text {; clinical } \\
\text { findings in PET } \\
\text { subgroup not } \\
\text { different) }\end{array}$ & & $\begin{array}{l}\text { chology: normal on group } \\
\text { level, unimpaired test } \\
\text { battery (15), but } \\
\text { individual pts. with } \\
\text { deficits in memory do- } \\
\text { main }(7 / 31) \text { or impaired } \\
\text { MoCA }(9 / 31) \text {, fatigue } \\
(19 / 31)\end{array}$ & $\begin{array}{l}\text { - comparison: } 45 \\
\text { control pts. (see } \\
\text { above, Hosp et al., } \\
\text { 2021) }\end{array}$ & & $\begin{array}{l}\text { correlation with clinical } \\
\text { scores }\end{array}$ & \\
\hline
\end{tabular}

For abbreviations see Table 1

*questionable anatomical localization, hard to differentiate from CSF spaces 


\section{FIGURES}

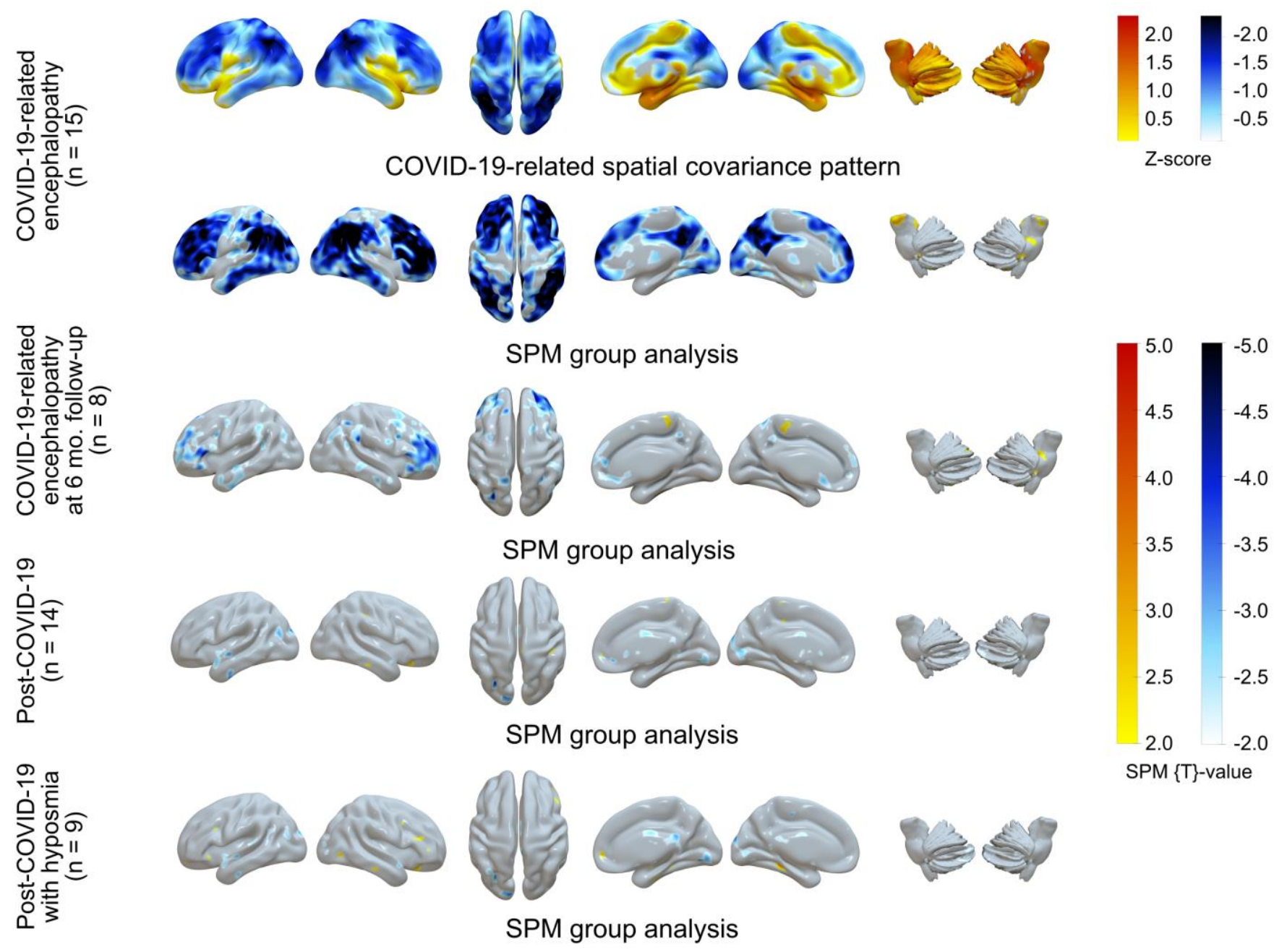

Figure 1: ${ }^{18}$ F-FDG PET in COVID-19-related CNS disorders: Confirmatory analyses

Principal components analysis of spatial covariance pattern (first row) and statistical parametric mapping (SPM) analysis of metabolic group differences (second to fifth rows) in patients with COVID-19-related encephalopathy ( $n=15$; first and second row, see Hosp et al., 2021 (18); of them $n=8$ at 6-month follow-up examination, third row, see Blazhenets et al., 2021 (41)), patients with Post-COVID-19 syndrome ( $n=14$; forth row) and patients with Post-COVID-19 
syndrome and hyposmia ( $n=9$; fifth row; see Dressing et al., 2021 (46)). Shown are lateral (right/left), superior and mesial (left/right) views of the cerebrum and lateral (right/left) views of the brain stem and cerebellum (from left to right column; overlay created with Surflce 2 software (https://www.nitrc.org/projects/surfice/)). Each analysis was performed in comparison to healthy controls $(n=13,7 / 6$ male/female, mean age $68 \pm 7$ years; PET performed under strictly comparable conditions), including age as covariate. SPM analyses entail count rate normalization to white matter (see Hosp et al., 2021 (18); virtually identical results were gained with scaling to pons, while scaling to total brain parenchyma resulted in apparent (artificial) hypermetabolism in subcortical structures in COVID-19-related encephalopathy; see also (40)). Of note, SPM results ( $t$ maps) were thresholded very liberally for comprehensive display of findings ( $t= \pm 2$, corresponding to $p \approx 0.05$, uncorrected). Only the extensive neocortical hypometabolism in COVID-19-related encephalopathy survives correction for multiple comparisons (voxel threshold $p<0.05$, false discovery rate-corrected). 


\section{REFERENCES}

1. Paterson RW, Brown RL, Benjamin L, et al. The emerging spectrum of COVID-19 neurology: clinical, radiological and laboratory findings. Brain. 2020;143:3104-3120.

2. Boesl F, Audebert H, Endres M, Prüss H, Franke C. A Neurological outpatient clinic for patients with post-COVID-19 syndrome - A report on the clinical presentations of the first 100 patients. Front Neurol. 2021;12:738405.

3. Romero-Sánchez CM, Díaz-Maroto I, Fernández-Díaz E, et al. Neurologic manifestations in hospitalized patients with COVID-19: The ALBACOVID registry. Neurology. 2020;95:e1060-e1070.

4. Zádori N, Váncsa S, Farkas N, Hegyi P, Erőss B, KETLAK Study Group. The negative impact of comorbidities on the disease course of COVID-19. Intensive Care Med. 2020;46:1784-1786.

5. NICE guideline [NG188], National Institute for Health and Care Excellence. COVID-19 rapid guideline: managing the long-term effects of COVID-19. December 2020.

6. Berlit P. Neurologische Manifestationen bei COVID-19 - Update vom 22.02.2021. Deutsche Gesellschaft für Neurologie (Hrsg), Leitlinien für Diagnostik und Therapie in der Neurologie Online: www.dgn.org/leitlinien. 2021.

7. Huang C, Wang Y, Li X, et al. Clinical features of patients infected with 2019 novel coronavirus in Wuhan, China. Lancet. 2020;395:497-506.

8. Frontera JA, Sabadia S, Lalchan R, et al. A prospective study of neurologic disorders in hospitalized patients with COVID-19 in New York city. Neurology. 2021;96:e575-e586.

9. Meppiel E, Peiffer-Smadja N, Maury A, et al. Neurologic manifestations associated with COVID-19: a multicentre registry. Clin Microbiol Infect. 2021;27:458-466.

10. Nannoni S, de Groot R, Bell S, Markus HS. Stroke in COVID-19: A systematic review and meta-analysis. Int J Stroke. 2021;16:137-149.

11. Andalib S, Biller J, Di Napoli M, et al. Peripheral Nervous System Manifestations Associated with COVID-19. Curr Neurol Neurosci Rep. 2021;21:9.

12. Palaiodimou L, Stefanou M-I, Katsanos AH, et al. Prevalence, clinical characteristics and outcomes of Guillain-Barré syndrome spectrum associated with COVID-19: A systematic review and meta-analysis. Eur J Neurol. 2021;28:3517-3529.

13. Finsterer J, Scorza FA. Infectious and immune-mediated central nervous system disease in 48 COVID-19 patients. J Clin Neurosci. 2021;90:140-143.

14. Halpin SJ, McIvor C, Whyatt G, et al. Postdischarge symptoms and rehabilitation needs in survivors of COVID-19 infection: A cross-sectional evaluation. J Med Virol. 2021;93:10131022. 
15. Garrigues E, Janvier P, Kherabi Y, et al. Post-discharge persistent symptoms and healthrelated quality of life after hospitalization for COVID-19. J Infect. 2020;81:e4-e6.

16. Almeria M, Cejudo JC, Sotoca J, Deus J, Krupinski J. Cognitive profile following COVID19 infection: Clinical predictors leading to neuropsychological impairment. Brain Behav Immun Health. 2020;9:100163.

17. Woo MS, Malsy J, Pöttgen J, et al. Frequent neurocognitive deficits after recovery from mild COVID-19. Brain Commun. 2020;2.

18. Hosp JA, Dressing A, Blazhenets G, et al. Cognitive impairment and altered cerebral glucose metabolism in the subacute stage of COVID-19. Brain. 2021;144:1263-1276.

19. Augustin M, Schommers P, Stecher M, et al. Post-COVID syndrome in non-hospitalised patients with COVID-19: a longitudinal prospective cohort study. Lancet Reg Health Eur. 2021;6:100122.

20. WHO Headquarters. A clinical case definition of post COVID-19 condition by a Delphi consensus, 6 October 2021. 2021.

21. Taquet M, Geddes JR, Husain M, Luciano S, Harrison PJ. 6-month neurological and psychiatric outcomes in 236379 survivors of COVID-19: a retrospective cohort study using electronic health records. Lancet Psychiatry. 2021;8:416-427.

22. Grimaldi S, Lagarde S, Harlé J-R, Boucraut J, Guedj E. Autoimmune encephalitis concomitant with SARS-CoV-2 infection: Insight from 18F-FDG PET imaging and neuronal autoantibodies. J Nucl Med. 2020;61:1726-1729.

23. Pizzanelli C, Milano C, Canovetti S, et al. Autoimmune limbic encephalitis related to SARS-CoV-2 infection: Case-report and review of the literature. Brain Behav Immun Health. 2021;12:100210.

24. Tiraboschi P, Xhani R, Zerbi SM, et al. Postinfectious neurologic complications in COVID19: A complex case report. J Nucl Med. 2021;62:1171-1176.

25. Méndez-Guerrero A, Laespada-García MI, Gómez-Grande A, et al. Acute hypokinetic-rigid syndrome following SARS-CoV-2 infection. Neurology. 2020;95:e2109-e2118.

26. Morassi M, Palmerini F, Nici S, et al. SARS-CoV-2-related encephalitis with prominent parkinsonism: clinical and FDG-PET correlates in two patients. J Neurol. 2021;268:39803987.

27. Cohen ME, Eichel R, Steiner-Birmanns B, et al. A case of probable Parkinson's disease after SARS-CoV-2 infection. Lancet Neurol. 2020;19:804-805.

28. Young MJ, O'Hare M, Matiello M, Schmahmann JD. Creutzfeldt-Jakob disease in a man with COVID-19: SARS-CoV-2-accelerated neurodegeneration? Brain Behav Immun. 2020;89:601-603. 
29. Niesen M, Trotta N, Noel A, et al. Structural and metabolic brain abnormalities in COVID19 patients with sudden loss of smell. Eur J Nucl Med Mol Imaging. 2021;48:1890-1901.

30. Karimi-Galougahi M, Yousefi-Koma A, Bakhshayeshkaram M, Raad N, Haseli S. 18FDG PET/CT scan reveals hypoactive orbitofrontal cortex in anosmia of COVID-19. Acad Radiol. 2020;27:1042-1043.

31. Guedj E, Million M, Dudouet P, et al. 18F-FDG brain PET hypometabolism in post-SARSCoV-2 infection: substrate for persistent/delayed disorders? Eur J Nucl Med Mol Imaging. 2021;48:592-595.

32. Yousefi-Koma A, Haseli S, Bakhshayeshkaram M, Raad N, Karimi-Galougahi M. Multimodality imaging with PET/CT and MRI reveals hypometabolism in tertiary olfactory cortex in parosmia of COVID-19. Acad Radiol. 2021;28:749-751.

33. Donegani MI, Miceli A, Pardini M, et al. Brain metabolic correlates of persistent olfactory dysfunction after SARS-Cov2 infection. Biomedicines. 2021;9:287.

34. Karimi-Galougahi M, Yousefi-Koma A, Raygani N, Bakhshayeshkaram M, Haseli S. 18FDG-PET/CT assessment of COVID-19-induced Bell's palsy. Acad Radiol. 2021;28:144-145.

35. Bozzali M, Grassini A, Morana G, et al. Focal seizures with impaired awareness as longterm neurological complication of COVID-19: a case report. Neurol Sci. 2021;42:26192623.

36. Chammas A, Bund C, Lersy F, et al. Collicular hyperactivation in patients with COVID-19: A new finding on brain MRI and PET/CT. AJNR Am J Neuroradiol. 2021;42:1410-1414.

37. Chammas A, Namer IJ, Lersy F, Kremer S, Bund C. Inferior colliculus's hypermetabolism: A new finding on brain FDG PET and perfusion MRI in a patient with COVID-19. Clin Nucl Med. 2021;46:413-414.

38. Delorme C, Paccoud O, Kas A, et al. COVID-19-related encephalopathy: a case series with brain FDG-positron-emission tomography/computed tomography findings. Eur J Neurol. 2020;27:2651-2657.

39. Kas A, Soret M, Pyatigoskaya N, et al. The cerebral network of COVID-19-related encephalopathy: a longitudinal voxel-based 18F-FDG-PET study. Eur J Nucl Med Mol Imaging. 2021;48:2543-2557.

40. Meyer PT, Blazhenets G, Prinz M, Hosp JA. Reply: From early limbic inflammation to long COVID sequelae. Brain. 2021;144:e66.

41. Blazhenets G, Schröter N, Bormann T, et al. Slow but evident recovery from neocortical dysfunction and cognitive impairment in a series of chronic COVID-19 patients. J Nucl Med. 2021;62:910-915. 
42. Hugon J, Msika E-F, Queneau M, Farid K, Paquet C. Long COVID: cognitive complaints (brain fog) and dysfunction of the cingulate cortex. J Neurol. June 2021:1-3.

43. Guedj E, Campion JY, Dudouet P, et al. 18F-FDG brain PET hypometabolism in patients with long COVID. Eur J Nucl Med Mol Imaging. 2021:1-11.

44. Morand A, Campion J-Y, Lepine A, et al. Similar patterns of [18F]-FDG brain PET hypometabolism in paediatric and adult patients with long COVID: a paediatric case series. Eur J Nucl Med Mol Imaging. 2021:1-8.

45. Sollini M, Morbelli S, Ciccarelli M, et al. Long COVID hallmarks on [18F]FDG-PET/CT: a case-control study. Eur J Nucl Med Mol Imaging. 2021;48:3187-3197.

46. Dressing A, Bormann T, Blazhenets G, et al. Neuropsychological profiles and cerebral glucose metabolism in neurocognitive Long COVID-syndrome. J Nucl Med. 2021. In Press.

47. Nieto I, Navas JF, Vázquez C. The quality of research on mental health related to the COVID-19 pandemic: A note of caution after a systematic review. Brain Behav Immun Health. 2020;7:100123.

48. Zhao S, Shibata K, Hellyer PJ, et al. Rapid vigilance and episodic memory decrements in COVID-19 survivors. preprint MedRxiv; 2021.

49. Voruz P, Allali G, Benzakour L, et al. Long COVID neuropsychological deficits after severe, moderate or mild infection. preprint MedRxiv; 2021.

50. Solomon IH, Normandin E, Bhattacharyya S, et al. Neuropathological Features of Covid19. N Engl J Med. 2020;383:989-992.

51. Matschke J, Lütgehetmann M, Hagel C, et al. Neuropathology of patients with COVID-19 in Germany: a post-mortem case series. Lancet Neurol. 2020;19:919-929.

52. Schwabenland M, Salié H, Tanevski J, et al. Deep spatial profiling of human COVID-19 brains reveals neuroinflammation with distinct microanatomical microglia-T-cell interactions. Immunity. 2021;54:1594-1610.e11.

53. Desforges M, Le Coupanec A, Dubeau P, et al. Human coronaviruses and other respiratory viruses: Underestimated opportunistic pathogens of the central nervous system? Viruses. 2019;12:14.

54. Dubé M, Le Coupanec A, Wong AHM, Rini JM, Desforges M, Talbot PJ. Axonal transport enables neuron-to-neuron propagation of human coronavirus OC43. Diamond MS, ed. $J$ Virol. 2018;92:e00404-18, /jvi/92/17/e00404-18.atom.

55. Mehta P, McAuley DF, Brown M, Sanchez E, Tattersall RS, Manson JJ. COVID-19: consider cytokine storm syndromes and immunosuppression. Lancet. 2020;395:1033-1034. 
56. Hernandez-Ronquillo L, Moien-Afshari F, Knox K, Britz J, Tellez-Zenteno JF. How to measure fatigue in epilepsy? The validation of three scales for clinical use. Epilepsy Res. 2011;95:119-129.

57. Billones R, Liwang JK, Butler K, Graves L, Saligan LN. Dissecting the fatigue experience: A scoping review of fatigue definitions, dimensions, and measures in non-oncologic medical conditions. Brain Behav Immun Health. 2021;15:100266.

58. Kinsinger SW, Lattie E, Mohr DC. Relationship between depression, fatigue, subjective cognitive impairment, and objective neuropsychological functioning in patients with multiple sclerosis. Neuropsychology. 2010;24:573-580.

59. Saligan LN, Olson K, Filler K, et al. The biology of cancer-related fatigue: a review of the literature. Support Care Cancer. 2015;23:2461-2478.

60. Bower JE. The role of neuro-immune interactions in cancer-related fatigue: Biobehavioral risk factors and mechanisms. Cancer. 2019;125:353-364.

61. Afari N, Buchwald D. Chronic fatigue syndrome: a review. Am J Psychiatry. 2003;160:221-236.

62. Townsend L, Dyer AH, Jones K, et al. Persistent fatigue following SARS-CoV-2 infection is common and independent of severity of initial infection. Madeddu G, ed. PLoS ONE. 2020;15:e0240784.

63. Price JR, Mitchell E, Tidy E, Hunot V. Cognitive behaviour therapy for chronic fatigue syndrome in adults. Cochrane Database Syst Rev. 2008:CD001027.

64. Bordonne M, Chawki MB, Doyen M, et al. Brain 18F-FDG PET for the diagnosis of autoimmune encephalitis: a systematic review and a meta-analysis. Eur J Nucl Med Mol Imaging. 2021;48:3847-3858.

65. Baumgartner A, Rauer S, Mader I, Meyer PT. Cerebral FDG-PET and MRI findings in autoimmune limbic encephalitis: correlation with autoantibody types. J Neurol. 2013;260:2744-2753.

66. Buchert R, Buhmann C, Apostolova I, Meyer PT, Gallinat J. Nuclear imaging in the diagnosis of clinically uncertain parkinsonian syndromes. Dtsch Arztebl Int. 2019;116:747754.

67. Meyer PT, Frings L, Rücker G, Hellwig S. 18F-FDG PET in parkinsonism: differential diagnosis and evaluation of cognitive impairment. J Nucl Med. 2017;58:1888-1898.

68. Chételat G, Arbizu J, Barthel H, et al. Amyloid-PET and 18F-FDG-PET in the diagnostic investigation of Alzheimer's disease and other dementias. Lancet Neurol. 2020;19:951-962. 


\title{
Supplement to
}

\section{Molecular imaging findings on acute and long-term effects of COVID-19 on the brain:}

A systematic review

\author{
Philipp T. Meyer ${ }^{1}$, Sabine Hellwig ${ }^{2}$, Ganna Blazhenets ${ }^{1}$ and Jonas A. Hosp ${ }^{3}$ \\ ${ }^{1}$ Department of Nuclear Medicine, ${ }^{2}$ Department of Psychiatry and Psychotherapy \\ and ${ }^{3}$ Department of Neurology and Clinical Neuroscience \\ Medical Center - University of Freiburg, \\ Faculty of Medicine, University of Freiburg, Freiburg, Germany
}

\section{Corresponding author:}

Philipp T. Meyer, MD, PhD

Department of Nuclear Medicine

Medical Center - University of Freiburg

Hugstetter Strasse 55

79106 Freiburg, Germany

Phone: +49 76127039160

Fax: $\quad+4976127039300$

Email: philipp.meyer@uniklinik-freiburg.de

Running head: Effects of COVID-19 on the brain 


\section{SUPPLEMENTAL TABLES}

Supplemental Table 1: Case reports on molecular imaging in cerebral manifestations of COVID-19

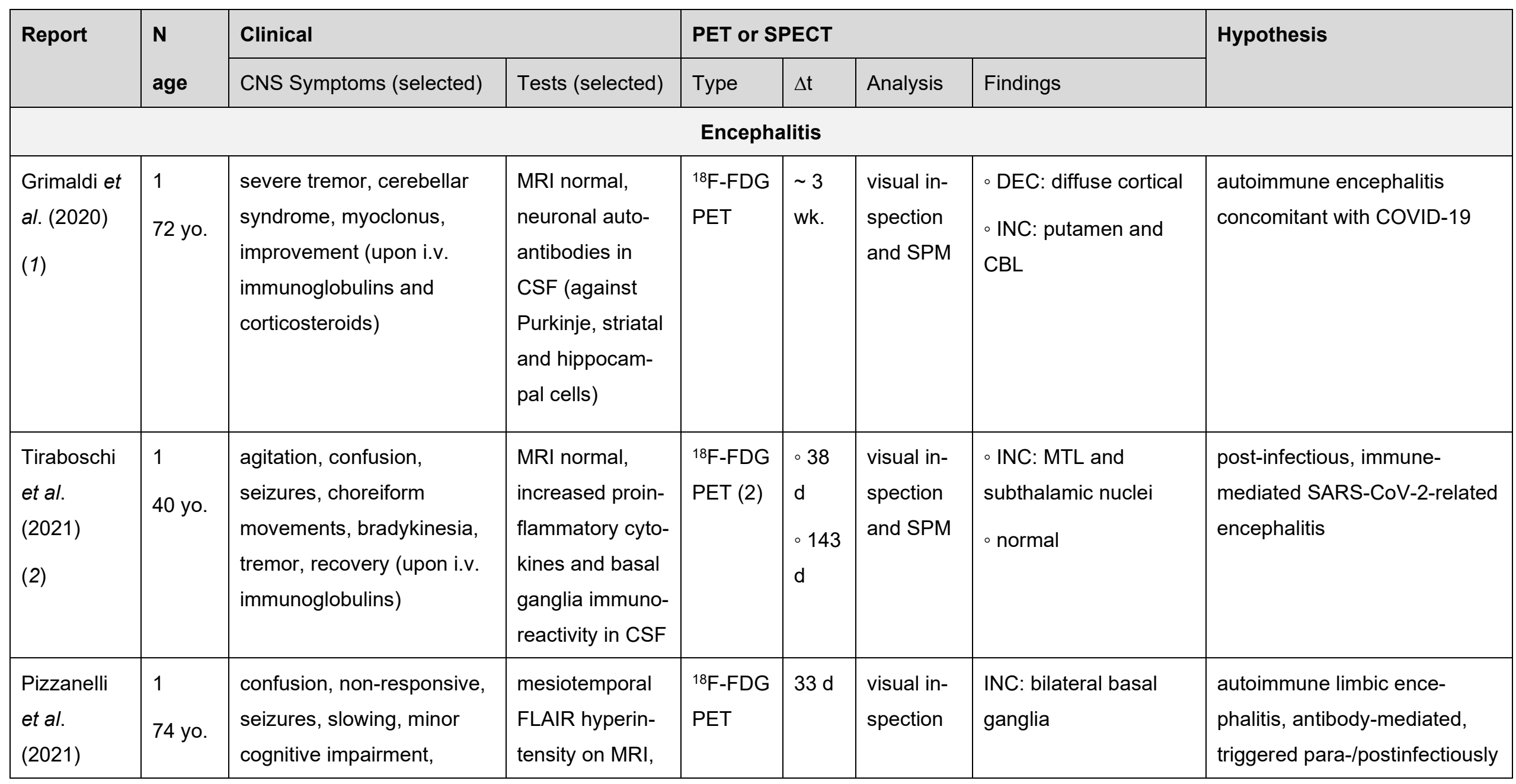




\begin{tabular}{|c|c|c|c|c|c|c|c|c|}
\hline \multirow[t]{2}{*}{ Report } & \multirow{2}{*}{$\begin{array}{l}\mathrm{N} \\
\text { age }\end{array}$} & \multicolumn{2}{|l|}{ Clinical } & \multicolumn{4}{|c|}{ PET or SPECT } & \multirow[t]{2}{*}{ Hypothesis } \\
\hline & & CNS Symptoms (selected) & Tests (selected) & Type & $\Delta \mathrm{t}$ & Analysis & Findings & \\
\hline (3) & & $\begin{array}{l}\text { improvement (i.v. } \\
\text { corticosteroids) }\end{array}$ & $\begin{array}{l}\text { CSF increased } \\
\text { protein }\end{array}$ & & & & & by SARS-CoV-2 \\
\hline \multicolumn{9}{|c|}{ Parkinsonism / Neurodegeneration } \\
\hline $\begin{array}{l}\text { Young et } \\
\text { al. (2020) } \\
(4)\end{array}$ & $\begin{array}{l}1 \\
60^{\text {ties }}\end{array}$ & $\begin{array}{l}\text { aphasia, cognitive } \\
\text { impairment, myoclonus, } \\
\text { progression to death ( } 2 \\
\text { mo.) }\end{array}$ & $\begin{array}{l}\text { MRI: It. hemi- } \\
\text { spheric FLAIR } \\
\text { hyperintensity, } \\
14-3-3 \text { in CSF }\end{array}$ & $\begin{array}{l}{ }^{18} \mathrm{~F}-\mathrm{FDG} \\
\text { PET }\end{array}$ & $\begin{array}{l}\sim 3 \\
w k\end{array}$ & $\begin{array}{l}\text { visual in- } \\
\text { spection }\end{array}$ & DEC: It. hemisphere & $\begin{array}{l}\text { Creutzfeldt-Jakob disease, } \\
\text { possibly precipitated and } \\
\text { accelerated by COVID-19- } \\
\text { related inflammatory cascade }\end{array}$ \\
\hline $\begin{array}{l}\text { Méndez- } \\
\text { Guerrero et } \\
\text { al. (2020) } \\
\text { (5) }\end{array}$ & $\begin{array}{l}1 \\
58 \text { yo. }\end{array}$ & $\begin{array}{l}\text { transient myoclonus and } \\
\text { tremor, fluctuating con- } \\
\text { sciousness, asymmetric } \\
\text { hypokinetic-rigid syndrome, } \\
\text { ocular deficits, } \\
\text { spontaneous improvement }\end{array}$ & $\begin{array}{l}\mathrm{CT}, \mathrm{CT} \\
\text { angiogram and } \\
\text { MRI normal, } \\
\text { neg. apomor- } \\
\text { phine test }\end{array}$ & $\begin{array}{l}\text { '123|- } \\
\text { FPCIT } \\
\text { SPECT } \\
.123 \mid- \\
\text { MIBG } \\
\text { scinti. }\end{array}$ & 7 wk. & $\begin{array}{l}\text { visual in- } \\
\text { spection } \\
\text { and ROI }\end{array}$ & $\begin{array}{l}\circ \text { DEC: asymmetric } \\
\text { nigrostriatal deficit } \\
\text { - normal cardiac } \\
\text { innervation }\end{array}$ & $\begin{array}{l}\text { SARS-CoV-2 can gain access } \\
\text { to the CNS and affect midbrain } \\
\text { structures }\end{array}$ \\
\hline $\begin{array}{l}\text { Cohen et } \\
\text { al. }(2020) \\
\text { (6) }\end{array}$ & $\begin{array}{l}1 \\
45 \text { yo. }\end{array}$ & $\begin{array}{l}\text { tremor, rigidity, } \\
\text { bradykinesia, intact } \\
\text { cognition, no RBD or } \\
\text { anosmia }\end{array}$ & $\begin{array}{l}\mathrm{CT} \text { and } \mathrm{MRI} \\
\text { normal, }\end{array}$ & $\begin{array}{l}{ }^{18} \mathrm{~F}- \\
\text { FDOPA } \\
\text { PET }\end{array}$ & $\begin{array}{l}\sim 2 \\
\text { mo. }\end{array}$ & $\begin{array}{l}\text { visual in- } \\
\text { spection }\end{array}$ & $\begin{array}{l}\text { DEC: bilateral } \\
\text { nigrostriatal deficit }\end{array}$ & $\begin{array}{l}\text { probable PD after COVID-19, } \\
\text { possibly due to genetic } \\
\text { vulnerability and/or } \\
\text { inflammation }\end{array}$ \\
\hline $\begin{array}{l}\text { Morassi et } \\
\text { al. }(2021) \\
\text { (7) }\end{array}$ & $\begin{array}{l}2 \\
70 / 73 \\
\text { yo. }\end{array}$ & $\begin{array}{l}\text { agitation/aggressive be- } \\
\text { havior (1), confusion (1), } \\
\text { lethargy (1), myoclonus ( } 1 \text { ), } \\
\text { fluctuating consciousness } \\
(1) \text {, seizures (1), tremor (1), }\end{array}$ & $\begin{array}{l}\text { progressive } \\
\text { ventricle enlar- } \\
\text { gement on MRI } \\
\text { (1), MRI normal } \\
\text { (1), low amyloid/ }\end{array}$ & $\begin{array}{l}\circ{ }^{18} \mathrm{~F}- \\
\text { FDG } \\
\text { PET }\end{array}$ & $\begin{array}{l}14- \\
20 d\end{array}$ & $\begin{array}{l}\text { visual in- } \\
\text { spection } \\
\text { and SPM }\end{array}$ & $\begin{array}{l}\circ \text { DEC: diffuse cortical } \\
\text { (esp. parietal) (2) } \\
\text { - INC: putamen (1), } \\
\text { MTL (2), cingulate (1), } \\
\text { brainstem (2), vermis }\end{array}$ & $\begin{array}{l}\text { parkinsonism and cognitive } \\
\text { decline due to SARS-CoV-2- } \\
\text { related encephalitis (similar to } \\
\text { encephalitis lethargica, post- } \\
\text { infectious immune-mediated); }\end{array}$ \\
\hline
\end{tabular}




\begin{tabular}{|c|c|c|c|c|c|c|c|c|}
\hline \multirow[t]{2}{*}{ Report } & \multirow{2}{*}{$\begin{array}{l}\mathrm{N} \\
\text { age }\end{array}$} & \multicolumn{2}{|l|}{ Clinical } & \multicolumn{4}{|c|}{ PET or SPECT } & \multirow[t]{2}{*}{ Hypothesis } \\
\hline & & CNS Symptoms (selected) & Tests (selected) & Type & $\Delta \mathrm{t}$ & Analysis & Findings & \\
\hline & & $\begin{array}{l}\text { rigidity (2), bradykinesia (2), } \\
\text { anarthria (1), dystonia (1), } \\
\text { progressive cognitive } \\
\text { impairment (1), no } \\
\text { improvement (2) }\end{array}$ & $\begin{array}{l}\text { high tau in CSF } \\
\text { (1), oligoclonal } \\
\text { bands in CSF } \\
\text { (1) }\end{array}$ & $\begin{array}{l}\text { ॰123|- } \\
\text { FPCIT } \\
\text { SPECT }\end{array}$ & & & $\begin{array}{l}\text { (1) } \\
\circ \text { DEC: nigrostriatal } \\
\text { deficit (1) }\end{array}$ & $\begin{array}{l}\text { alternatively, COVID-19- } \\
\text { related acceleration of pre- } \\
\text { clinical neurodegenerative } \\
\text { disease }\end{array}$ \\
\hline \multicolumn{9}{|c|}{ Focal Symptoms/Lesions } \\
\hline $\begin{array}{l}\text { Karimi-Ga- } \\
\text { lougahi et } \\
\text { al. }(2020) \\
(8)\end{array}$ & $\begin{array}{l}1 \\
27 \text { yo. }\end{array}$ & persistent anosmia & $\begin{array}{l}\text { no details } \\
\text { reported }\end{array}$ & $\begin{array}{l}{ }^{18} \mathrm{~F}-\mathrm{FDG} \\
\text { PET }\end{array}$ & $\begin{array}{l}\sim 6 \\
\text { wk. }\end{array}$ & $\begin{array}{l}\text { visual in- } \\
\text { spection } \\
\text { and ROI }\end{array}$ & DEC: left orbitofrontal & $\begin{array}{l}\text { impaired cortical function due } \\
\text { to direct neurotropism of } \\
\text { SARS-CoV-2 via olfactory bulb }\end{array}$ \\
\hline $\begin{array}{l}\text { Guedj et al. } \\
(2021) \\
(9)\end{array}$ & $\begin{array}{l}2 \\
54 / 62 \\
\text { yo. }\end{array}$ & $\begin{array}{l}\text { prolonged anosmia and } \\
\text { memory complaints (1), } \\
\text { painful sensation in rt./lt. } \\
\text { toes (1) }\end{array}$ & $\begin{array}{l}\text { no details } \\
\text { reported }\end{array}$ & $\begin{array}{l}{ }^{18} \mathrm{~F}-\mathrm{FDG} \\
\text { PET }\end{array}$ & $\begin{array}{l}\sim 2-8 \\
\text { wk. }\end{array}$ & $\begin{array}{l}\text { visual in- } \\
\text { spection } \\
\text { and SPM }\end{array}$ & $\begin{array}{l}\circ \mathrm{DEC} \text { : rectal gyrus (2); } \\
\text { limbic regions, SMC, } \\
\text { thalamus, CBL, } \\
\text { brainstem (1) }\end{array}$ & $\begin{array}{l}\text { neurotropism of SARS-CoV-2 } \\
\text { via olfactory bulb (independent } \\
\text { of hyposmia), extension of } \\
\text { impairment to limbic and other } \\
\text { structures }\end{array}$ \\
\hline $\begin{array}{l}\text { Karimi- } \\
\text { Galougahi } \\
\text { et al. } \\
(2021) \\
(10)\end{array}$ & $\begin{array}{l}1 \\
60 \text { yo. }\end{array}$ & facial nerve palsy rt. & $\begin{array}{l}\text { no details } \\
\text { reported }\end{array}$ & $\begin{array}{l}{ }^{18} \mathrm{~F}-\mathrm{FDG} \\
\text { PET }\end{array}$ & n.a. & $\begin{array}{l}\text { visual in- } \\
\text { spection } \\
\text { and ROI }\end{array}$ & $\begin{array}{l}\text { DEC: right facial } \\
\text { nerve }^{*}\end{array}$ & $\begin{array}{l}\text { reduced CBF secondary to } \\
\text { micro-thrombosis caused by } \\
\text { SARS-CoV-2-induced } \\
\text { endothelial injury }\end{array}$ \\
\hline Bozzali et & 1 & anosmia, fatigue, gait & epileptic activity & ${ }^{18} \mathrm{~F}-\mathrm{FDG}$ & $\sim 4$ & visual in- & normal & subacute encephalitis due to \\
\hline
\end{tabular}




\begin{tabular}{|c|c|c|c|c|c|c|c|c|}
\hline \multirow[t]{2}{*}{ Report } & \multirow{2}{*}{$\begin{array}{l}\mathrm{N} \\
\text { age }\end{array}$} & \multicolumn{2}{|l|}{ Clinical } & \multicolumn{4}{|c|}{ PET or SPECT } & \multirow[t]{2}{*}{ Hypothesis } \\
\hline & & CNS Symptoms (selected) & Tests (selected) & Type & $\Delta \mathrm{t}$ & Analysis & Findings & \\
\hline $\begin{array}{l}\text { al. (2021) } \\
\text { (11) }\end{array}$ & 54 yo. & $\begin{array}{l}\text { imbalance, headache, } \\
\text { olfactory hallucinations / } \\
\text { focal seizures, confusion }\end{array}$ & $\begin{array}{l}\text { on EEG, } \\
\text { increased BAEP } \\
\text { latencies }\end{array}$ & PET & mo. & spection & & SARS-CoV-2 CNS infection \\
\hline $\begin{array}{l}\text { Chammas } \\
\text { et al. } \\
(2021) \\
(12)\end{array}$ & $\begin{array}{l}1 \\
64 \text { yo. }\end{array}$ & Confusion & $\begin{array}{l}\text { hyperperfusion } \\
\text { on MRI }\end{array}$ & $\begin{array}{l}{ }^{18} \mathrm{~F}-\mathrm{FDG} \\
\text { PET }\end{array}$ & $\begin{array}{l}\sim 2 \\
\text { mo. }\end{array}$ & $\begin{array}{l}\text { visual in- } \\
\text { spection } \\
\text { and ROI }\end{array}$ & $\begin{array}{l}\text { INC: bilateral inferior } \\
\text { colliculi }\end{array}$ & $\begin{array}{l}\text { possible inflammatory reaction } \\
\text { (e.g., vasculitis/ encephalitis) } \\
\text { in persistence of COVID-19 }\end{array}$ \\
\hline $\begin{array}{l}\text { Yousef- } \\
\text { Koma et al. } \\
(2021) \\
(13)\end{array}$ & $\begin{array}{l}1 \\
28 \text { yo. }\end{array}$ & $\begin{array}{l}\text { anosmia developing into } \\
\text { parosmia }\end{array}$ & MRI normal & $\begin{array}{l}{ }^{18} \mathrm{~F}-\mathrm{FDG} \\
\text { PET }\end{array}$ & $\begin{array}{l}\sim 6 \\
\text { mo. }\end{array}$ & $\begin{array}{l}\text { visual in- } \\
\text { spection } \\
\text { and ROI }\end{array}$ & $\begin{array}{l}\text { DEC: It. insula, IFG, } \\
\text { hippocampus, } \\
\text { amygdala }\end{array}$ & $\begin{array}{l}\text { functionally impaired tertiary } \\
\text { olfactory cortex due to neuro- } \\
\text { invasion by SARS-CoV-2 }\end{array}$ \\
\hline \multicolumn{9}{|c|}{ Encephalopathy / Long COVID } \\
\hline $\begin{array}{l}\text { Delorme at } \\
\text { al. }(2020) \\
(14)\end{array}$ & $\begin{array}{l}4 \\
60-72 \\
\text { yo. }\end{array}$ & $\begin{array}{l}\text { agitation (2), slowing (2) } \\
\text { seizures (1), frontal lobe (3) } \\
\text { or dysexecutive (1) } \\
\text { syndrome, apraxia (1), } \\
\text { myoclonus (1), ataxia (2), } \\
\text { partial (1) to full (2) } \\
\text { recovery up to } 10 \mathrm{wk} .\end{array}$ & $\begin{array}{l}\text { orbitofrontal } \\
\text { hyperintensity } \\
\text { on T2 MRI (1), } \\
\text { low amyloid (2) } \\
\text { and high tau (1) } \\
\text { in CSF }\end{array}$ & $\begin{array}{l}{ }^{18} \text { F-FDG } \\
\text { PET }\end{array}$ & $\begin{array}{l}14- \\
41 \mathrm{~d} .\end{array}$ & $\begin{array}{l}\text { visual in- } \\
\text { spection }\end{array}$ & $\begin{array}{l}\text { - DEC: bilateral (orbito- } \\
\text { ) frontal (4), parieto- } \\
\text { temporal (3) } \\
\text { - INC: striatum (2) \& } \\
\text { vermis (4) }\end{array}$ & $\begin{array}{l}\text { COVID-19-related encephalo- } \\
\text { pathy of suspected immune } \\
\text { mechanism (parainfectious } \\
\text { cytokine storm or antibody- or } \\
\text { cell-mediated; possibly under- } \\
\text { lying neurodegeneration (2)) }\end{array}$ \\
\hline $\begin{array}{l}\text { Hugon et } \\
\text { al. }(2021)\end{array}$ & $\begin{array}{l}2 \\
43 / 45\end{array}$ & $\begin{array}{l}\text { memory impairment (2), } \\
\text { slowness of ideation (1), }\end{array}$ & $\begin{array}{l}\text { mildly impaired } \\
\text { episodic (2) / }\end{array}$ & $\begin{array}{l}{ }^{18} \mathrm{~F}-\mathrm{FDG} \\
\text { PET }\end{array}$ & $\begin{array}{l}3-7 \\
\text { mo. }\end{array}$ & $\begin{array}{l}\text { Z score, } \\
\text { surface }\end{array}$ & $\begin{array}{l}\text { DEC: anterior (2) and } \\
\text { posterior (1) cingulate }\end{array}$ & $\begin{array}{l}\text { long-standing brain } \\
\text { dysfunction due to hypoxia }\end{array}$ \\
\hline
\end{tabular}




\begin{tabular}{|c|c|c|c|c|c|c|c|c|}
\hline \multirow[t]{2}{*}{ Report } & \multirow{2}{*}{$\begin{array}{l}\mathrm{N} \\
\text { age }\end{array}$} & \multicolumn{2}{|l|}{ Clinical } & \multicolumn{4}{|c|}{ PET or SPECT } & \multirow[t]{2}{*}{ Hypothesis } \\
\hline & & CNS Symptoms (selected) & Tests (selected) & Type & $\Delta \mathrm{t}$ & Analysis & Findings & \\
\hline (15) & yo. & $\begin{array}{l}\text { fatigue (2), anxiety (1), } \\
\text { walking and speech } \\
\text { difficulties (1) }\end{array}$ & $\begin{array}{l}\text { visuospatial (1) } \\
\text { memory and } \\
\text { executive } \\
\text { functions (2), } \\
\text { MRI normal (2) }\end{array}$ & & & $\begin{array}{l}\text { rendering } \\
\text { (liberal } \\
\text { threshold) }\end{array}$ & gyrus, precuneus $(1)^{\star *}$ & $\begin{array}{l}\text { and/or delayed } \\
\text { neuroinflammation }\end{array}$ \\
\hline
\end{tabular}

Abbreviations: PET, positron emission tomography; SPECT, single-photon computed tomography; FDG, 2-deoxy-2-[18 $\mathrm{F}]$ fluoroglucose (target parameter: glucose metabolism); FDOPA, 6-[18F]fluoro-L-dihydroxyphenylalanin (dopamine synthesis and storage); FPCIT, N- $\omega$-fluoropropyl- $2 \beta-$

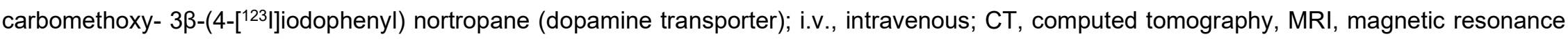
imaging; CBF, cerebral blood flow; COVID-19, coronavirus disease 2019; SARS-CoV-2, severe acute respiratory syndrome coronavirus 2; N, number of patients, numbers in parenthesis refer to number of subjects with specified finding (if the subsample assessed is smaller than study group, sample size as indicated); $\Delta \mathrm{t}$, time interval between symptom onset or positive polymerase chain reaction (PCR+) for SARS-CoV-2 (as available) and PET; CSF, cerebrospinal fluid; RBD, REM sleep behavior disorder; EEG, electroencephalography; BAEP, brainstem auditory evoked potential; FLAIR, fluid-attenuated inversion recovery; n.a., information not available; d, day; wk., week; mo., month; yo., years-old; ROI, region of interest analysis; SPM, statistical parametric mapping (single-subject analysis vs. controls); INC and DEC, increased and decreased signal, respectively; It./rt., left/right; CN, caudate nucleus; CBL, cerebellum; MTL, mesial temporal lobe; IFG, inferior frontal gyrus; SMC, sensorimotor cortex.

*possible erroneous anatomical localization, Figure 1 in Karimi-Galougahi et al. (2021) may show right cerebellar flocculus.

** possible erroneous anatomical localization, Figure 1, Patient 1 in Hugon et al. (2021) shows more prominent finding in cuneus (visual cortex) than precuneus. 


\section{Supplemental Table 2: Systematic studies on molecular imaging in cerebral manifestations of COVID-19: Focal Symptoms/Lesions}

\begin{tabular}{|c|c|c|c|c|c|c|c|c|}
\hline \multirow[t]{2}{*}{ Report } & \multirow{2}{*}{$\begin{array}{l}\text { Research } \\
\text { Question }\end{array}$} & \multicolumn{3}{|l|}{ Population } & \multicolumn{3}{|l|}{ FDG PET } & \multirow[t]{2}{*}{ Hypothesis } \\
\hline & & Inclusion (main) & $\begin{array}{l}\mathrm{N} \\
\text { age }\end{array}$ & $\begin{array}{l}\text { Clinical Findings } \\
\text { (selected) }\end{array}$ & Analysis & $\Delta \mathrm{t}$ & Major Findings & \\
\hline $\begin{array}{l}\text { Niesen et } \\
\text { al. (2021) } \\
(16)\end{array}$ & $\begin{array}{l}\text { metabolic } \\
\text { pattern of } \\
\text { dysosmia } \\
\text { in COVID- } \\
19 \\
\text { (see report } \\
\text { for MRI) }\end{array}$ & $\begin{array}{l}\circ \text { PCR+ } \\
\text { - sudden loss of } \\
\text { smell }\end{array}$ & $\begin{array}{l}23-60 \\
\text { yo. }\end{array}$ & $\begin{array}{l}\text { outpatients (11), one } \\
\text { hospitalized (1) } \\
\text { o hyposmia (5) or ano- } \\
\text { smia (7); no other } \\
\text { neurological sign } \\
\text { except headache (6) } \\
\text { - follow-up up to } 16 \\
\text { weeks, improvement in } \\
\text { all (virtually normal [5]) }\end{array}$ & $\begin{array}{l}\text { SPM: single- } \\
\text { subject \& group } \\
\text { - normalization: } \\
\text { proportional } \\
\text { scaling } \\
\text { comparison: } 26 \\
\text { NC (other studies) } \\
\circ p<0.05 \text { FWE } \\
\text { and } p<0.001\end{array}$ & $\begin{array}{l}15 \pm 9 \\
d\end{array}$ & $\begin{array}{l}\text { - with FWE correction no } \\
\text { significant finding } \\
\text { ' with liberal threshold (single- } \\
\text { subject \& group) multiple small, } \\
\text { widespread and partially } \\
\text { contradictory findings (DEC \& INC; } \\
\text { pos./neg. correlations with } \\
\text { olfactory performance and duration } \\
\text { of dysosmia) }\end{array}$ & $\begin{array}{l}\text { subtle regional } \\
\text { metabolic chan-ges } \\
\text { in olfactory and } \\
\text { high-order networks, } \\
\text { secondary due to } \\
\text { olfactory deficit } \\
\text { rather than neuro- } \\
\text { invasion of SARS- } \\
\text { CoV-2 }\end{array}$ \\
\hline $\begin{array}{l}\text { Donegani } \\
\text { et al. } \\
(2021) \\
(17)\end{array}$ & $\begin{array}{l}\text { metabolic } \\
\text { signature } \\
\text { of persis- } \\
\text { tent Isola- } \\
\text { ted hypos- } \\
\text { mia after } \\
\text { COVID-19 }\end{array}$ & $\begin{array}{l}\text { ॰ pts. undergoing } \\
\text { whole-body PET/ } \\
\text { CT with dedicated } \\
\text { brain PET } \\
\text { o previous SARS- } \\
\text { CoV-2 (PCR+) } \\
\text { o isolated hypos- } \\
\text { mia in recovery } \\
\text { phase (PCR-) }\end{array}$ & $\begin{array}{l}14 \\
64 \pm 11 \\
\text { yo. }\end{array}$ & $\begin{array}{l}\text { - pts. with mechanical } \\
\text { ventilation excluded } \\
\text { - no lesion on MRI } \\
\text { - olfactory test: median } \\
4 \text { of } 8 \text { odors correct } \\
\text { (range: } 2-6 \text { ) }\end{array}$ & $\begin{array}{l}\text { - dedicated brain } \\
\text { scan (2 scanners) } \\
\text {-SPM: group } \\
\text { o normalization: } \\
\text { proportional } \\
\text { scaling (global) } \\
\text { - comparison: } 61 \\
\text { (NC and control } \\
\text { pts.; } 2 \text { scanners) } \\
\circ \text { p < } 0.05 \text { FWE }\end{array}$ & $\begin{array}{l}4-14 \\
\text { wk. }\end{array}$ & $\begin{array}{l}\text { - DEC: bilateral parahippocampal } \\
\text { and fusiform gyri and left insula }\end{array}$ & $\begin{array}{l}\text { cortical } \\
\text { deafferentiation due } \\
\text { to persistent } \\
\text { impairment of } \\
\text { transmission along } \\
\text { the olfactory } \\
\text { pathway (no prove } \\
\text { of direct spread of } \\
\text { virus) }\end{array}$ \\
\hline
\end{tabular}




\begin{tabular}{|c|c|c|c|c|c|c|c|c|}
\hline \multirow[t]{2}{*}{ Report } & \multirow{2}{*}{$\begin{array}{l}\text { Research } \\
\text { Question }\end{array}$} & \multicolumn{3}{|l|}{ Population } & \multicolumn{3}{|l|}{ FDG PET } & \multirow[t]{2}{*}{ Hypothesis } \\
\hline & & Inclusion (main) & $\begin{array}{l}\mathrm{N} \\
\text { age }\end{array}$ & $\begin{array}{l}\text { Clinical Findings } \\
\text { (selected) }\end{array}$ & Analysis & $\Delta \mathrm{t}$ & Major Findings & \\
\hline $\begin{array}{l}\text { Chammas } \\
\text { et al. } \\
(2021) \\
(18)\end{array}$ & $\begin{array}{l}\text { inferior col- } \\
\text { liculi hyper- } \\
\text { activity: } \\
\text { new finding } \\
\text { on MRI } \\
\text { and PET } \\
\text { (for MRI } \\
\text { see report) }\end{array}$ & $\begin{array}{l}\text { - retrospective } \\
\text { - PCR+ } \\
\text { - neurological } \\
\text { symptomatology } \\
\text { leading to MRI } \\
\text { - criteria for PET } \\
\text { not specified }\end{array}$ & $\begin{array}{l}13 \\
(\mathrm{PET})\end{array}$ & $\begin{array}{l}\circ 90 \% \text { of MRI popula- } \\
\text { tion (112) hospitalized } \\
\text { o rather severe symp- } \\
\text { toms, e.g.: impaired } \\
\text { consciousness [50\%], } \\
\text { confusion [43\%], } \\
\text { pyramidal tract sign } \\
\text { [26\%], agitation [25\%] }\end{array}$ & $\begin{array}{l}\circ \text { visual reads } \\
\circ \text { ROI analyses: } \\
\text { colliculi uptake } \\
20 \% \text { above } \\
\text { mesencephalon } \\
\text { considered as INC }\end{array}$ & $\begin{array}{l}30 \mathrm{~d} \\
(2) \text { or } 3 \\
\text { mo. } \\
(12) \\
4(2) \text { or } \\
12(12) \\
\text { wk. }\end{array}$ & $\begin{array}{l}\circ 8 / 9 \text { pts. with hyperper-fusion of } \\
\text { colliculi on MRI and available PET } \\
\text { also showed INC on PET; } \\
\text {-5/5 pts. without hyperper-fusion } \\
\text { showed no INC } \\
\text { - association with more seizures } \\
\text { and higher leukocytes, not with } \\
\text { clinical severity or prognosis }\end{array}$ & $\begin{array}{l}\text { cytokine storm } \\
\text { causes hyperacti- } \\
\text { vation }\end{array}$ \\
\hline
\end{tabular}

For abbreviations see Table 1; SPM: single-subject and/or group, SPM group and/or single-subject analyses (usually COVID-19 patient or patients vs. controls); normalization, method/reference region used for count rate normalization of PET scans; FWE, family-wise error correction; NC, normal controls. 


\section{REFERENCES}

1. Grimaldi S, Lagarde S, Harlé J-R, Boucraut J, Guedj E. Autoimmune encephalitis concomitant with SARS-CoV-2 infection: Insight from 18F-FDG PET imaging and neuronal Autoantibodies. J Nucl Med. 2020;61:1726-1729.

2. Tiraboschi P, Xhani R, Zerbi SM, et al. Postinfectious Neurologic Complications in COVID-19: A Complex Case Report. J Nucl Med. 2021;62:1171-1176.

3. Pizzanelli C, Milano C, Canovetti S, et al. Autoimmune limbic encephalitis related to SARS-CoV-2 infection: Case-report and review of the literature. Brain Behav Immun Health. 2021;12:100210.

4. Young MJ, O'Hare M, Matiello M, Schmahmann JD. Creutzfeldt-Jakob disease in a man with COVID-19: SARS-CoV-2-accelerated neurodegeneration? Brain Behav Immun. 2020;89:601-603.

5. Méndez-Guerrero A, Laespada-García MI, Gómez-Grande A, et al. Acute hypokinetic-rigid syndrome following SARS-CoV-2 infection. Neurology. 2020;95:e2109-e2118.

6. Cohen ME, Eichel R, Steiner-Birmanns B, et al. A case of probable Parkinson's disease after SARS-CoV-2 infection. Lancet Neurol. 2020;19:804-805.

7. Morassi M, Palmerini F, Nici S, et al. SARS-CoV-2-related encephalitis with prominent parkinsonism: clinical and FDG-PET correlates in two patients. J Neurol. 2021;268:39803987.

8. Karimi-Galougahi M, Yousefi-Koma A, Bakhshayeshkaram M, Raad N, Haseli S. 18FDG PET/CT Scan Reveals Hypoactive Orbitofrontal Cortex in Anosmia of COVID-19. Acad Radiol. 2020;27:1042-1043.

9. Guedj E, Million M, Dudouet P, et al. 18F-FDG brain PET hypometabolism in post-SARSCoV-2 infection: substrate for persistent/delayed disorders? Eur J Nucl Med Mol Imaging. 2021;48:592-595.

10. Karimi-Galougahi M, Yousefi-Koma A, Raygani N, Bakhshayeshkaram M, Haseli S. 18FDG-PET/CT assessment of COVID-19-induced Bell's palsy. Acad Radiol. 2021;28:144-145.

11. Bozzali M, Grassini A, Morana G, et al. Focal seizures with impaired awareness as longterm neurological complication of COVID-19: a case report. Neurol Sci. 2021;42:26192623.

12. Chammas A, Bund C, Lersy F, et al. Collicular hyperactivation in patients with COVID-19: A new finding on brain MRI and PET/CT. AJNR Am J Neuroradiol. 2021;42:1410-1414. 
13. Yousefi-Koma A, Haseli S, Bakhshayeshkaram M, Raad N, Karimi-Galougahi M. Multimodality Imaging With PET/CT and MRI Reveals Hypometabolism in Tertiary Olfactory Cortex in Parosmia of COVID-19. Acad Radiol. 2021;28:749-751.

14. Delorme C, Paccoud O, Kas A, et al. COVID-19-related encephalopathy: a case series with brain FDG-positron-emission tomography/computed tomography findings. Eur J Neurol. 2020;27:2651-2657.

15. Hugon J, Msika E-F, Queneau M, Farid K, Paquet C. Long COVID: cognitive complaints (brain fog) and dysfunction of the cingulate cortex. J Neurol. June 2021:1-3.

16. Niesen M, Trotta N, Noel A, et al. Structural and metabolic brain abnormalities in COVID19 patients with sudden loss of smell. Eur J Nucl Med Mol Imaging. 2021;48:1890-1901.

17. Donegani MI, Miceli A, Pardini M, et al. Brain metabolic correlates of persistent olfactory dysfunction after SARS-Cov2 infection. Biomedicines. 2021;9:287.

18. Chammas A, Namer IJ, Lersy F, Kremer S, Bund C. Inferior colliculus's hypermetabolism: A new finding on brain FDG PET and perfusion MRI in a patient with COVID-19. Clin Nucl Med. 2021;46:413-414. 